How to cite: Tuğaç, M. G \& F. Sefer, 2021. Türkiye'de zeytin (Olea europaea L.) üretimine uygun alanların coğrafi bilgi sistemleri (CBS) tabanlı çoklu kriter analizi ile belirlenmesi, Ege Univ. Ziraat Fak. Derg., 58 (1): 97-113, https://doi.org/10.20289/zfdergi.678474

\begin{tabular}{|l|}
\hline $\begin{array}{l}\text { Araştırma Maalesi } \\
\text { (Research Article) }\end{array}$ \\
\hline
\end{tabular}

Murat Güven TUĞAÇ ${ }^{\text {* }}$

Filiz SEFER ${ }^{2}$ iD

${ }^{1}$ Tarla Bitkileri Merkez Araştırma Enstitüsü Müdürlüğü, Ankara / Türkiye

${ }^{2}$ Zeytincilik Araştırma Enstitüsü Müdürlüğü, Bornova-İzmir / Türkiye

*iletişim (correspondence) e-posta: mgtugac@gmail.com

Anahtar sözcükler: Zeytin, ürün uygunluk sınıflaması, çok kriterli analiz, analitik hiyerarşi süreci, coğrafi bilgi sistemleri

Keywords: Olive, crop suitability classification, multi-criteria analysis, analytic hierarchy process, geographic information systems
Ege Üniv. Ziraat Fak. Derg., 2021, 58 (1):97-113 https://doi.org/10.20289/zfdergi.678474

\section{Türkiye'de zeytin (Olea europaea L.) üretimine uygun alanların coğrafi bilgi sistemleri (CBS) tabanlı çoklu kriter analizi ile belirlenmesi}

\author{
GIS-based multi-criteria land suitability analysis \\ for determining olive (Olea Europaea L.) \\ cultivation areas in Turkey
}

Alınış (Received): 27.01.2020

Kabul Tarihi (Accepted): 03.06.2020

Öz

Amaç: Bu çalışmada, Türkiye'de iklim, toprak ve topoğrafik faktörlere göre zeytin yetiştiriciliği için optimum yetişme koşulları ve potansiyel arazi uygunluk sınıfları belirlenmiştir.

Materyal ve Yöntem: Zeytin yetiştiriciliği için arazi uygunluğunun belirlenmesinde, Coğrafi Bilgi Sistemleri Tabanlı Çok Kriterli Karar Verme yöntemi uygulanmıştır. Bu kapsamda; yıllık ortalama sıcaklık, Ocak ayı mutlak minimum sıcaklık, Ocak ayı ortalama sıcaklık, Mayıs ayı ortalama sıcaklık, yaz dönemi ortalama maksimum sıcaklık, nem, yağış, arazi kullanım kabiliyeti sınıfları, toprak derinliği, kısıtlayıcı toprak özellikleri, erozyon, yükseklik ve eğim değerlendirme kriterleri olarak alınmış ve uygunluk sınır değerleri belirlenmiştir. Analitik Hiyerarşi Süreci yaklaşımı ile kriterlerin birbirlerine göre göreceli üstünlükleri belirlenerek kriter ağılıklıları atanmış ve ürün uygunluk sınıfları oluşturulmuştur.

Araştırma Bulguları: Zeytin üretimi için Türkiye'nin \% 6.7'si (5 254937 ha) yetiştirmeye uygun alanları oluştururken, orta derecede uygun alanlar \% 6.3 (4 940 932 ha). oranında yer almıştır. Zeytin üretimi yapılan uygun alanlarda; yıllık ortalama sıcaklık $16.8^{\circ} \mathrm{C}$, mutlak minimum sıcaklık $-2.8^{\circ} \mathrm{C}$, Ocak ayı ortalama sıcaklık $7.0^{\circ} \mathrm{C}$, Mayıs ayı ortalama sıcaklık $19.6^{\circ} \mathrm{C}$ ve yıllık toplam yağış $668 \mathrm{~mm}$ olarak belirlenmiştir.

Sonuç: Zeytin yetiştiriciliğinde bölgesel farklılıkların oluşmasında sıcaklık en önemli ve ağırlıklı faktördür. CBS tabanlı çok kriterli değerlendirme yöntemi, ürün uygunluk sınıflamasında etkin olarak kullanılmıştır.

\section{ABSTRACT}

Objective: In this study, optimum growing conditions and potential land suitability classes for olive cultivation were determined according to climatic, soil and topographic factors in Turkey.

Material and Methods: In determining land suitability for olive production, Geographical Information Systems Based Multiple Criteria Decision Making method was applied. In this context; The annual average temperature, January absolute minimum temperature, January average temperature, May average temperature, average summer maximum temperature, humidity, rainfall, land use capability subclass, soil depth, restrictive soil properties, erosion degree, altitude and slope were evaluated. Each criterion layer is produced in raster data format. With the AHP approach, the degree of influence of the criteria was determined and criterion weights were assigned. Land suitability classes were created by combining criterion maps with linear combination method.

Results: The potential suitability map for olive production was obtained in four classes as very suitable, medium suitable, less suitable and unsuitable. For olive production, $6.7 \%$ (5 $254937 \mathrm{ha}$ ) of Turkey accounted for areas suitable for cultivation, while moderately suitable areas accounted for $6.3 \%$ (4 940932 ha). In suitable areas where olive production is made; The average annual temperature is $16.8^{\circ} \mathrm{C}$, the absolute minimum temperature is $-2.8^{\circ} \mathrm{C}$, the average temperature for January is $7.0^{\circ} \mathrm{C}$, the average temperature for May is $19.6^{\circ} \mathrm{C}$ and the total annual precipitation is $668 \mathrm{~mm}$.

Conclusion: Temperature is the most important and weighted factor in the formation of regional differences in olive cultivation. GIS-based multi-criteria evaluation method has been used effectively in crop suitability classification. 


\section{Giriş}

Zeytin (Olea europaea L.), Akdeniz iklimini karakterize eden ekonomik değeri yüksek olan bir üründür. Zeytin, ekolojik açıdan dünyanın belirli bölgelerinde yaşam alanı bulmuştur. Genel olarak, Güney ve Kuzey yarım kürenin $30^{\circ}-45^{\circ}$ enlemleri arası, zeytinin üretim kuşağı olarak kabul edilmektedir. Zeytin ağacı kışları ılık ve yağmurlu, yazları sıcak ve kurak olan Akdeniz ikliminde en iyi yetişme koşullarını bulmaktadır. Zeytin peyzajı, Akdeniz Bölgesini en temsili kültürel çevrelerinden biri olarak kabul edilir (Loumou and Giourga, 2003). Zeytin üretimi yapılan alanların \% 98'i Akdeniz ekolojisine sahip ülkelerde bulunmaktadır (Anonim, 2006).

Dünya'da zeytin üretimi yapılan 10,513,320 hektar alanda $21,066,062$ ton dane zeytin elde edilmektedir. Zeytin üretim alanlarının büyük bir çoğunluğu Akdeniz ülkelerinde bulunmaktadır. Dünya zeytinyağı rekoltesi yaklaşık 3,2 milyon ton düzeyinde olup zeytinyağı üretimin de önemli ülkeler arasında sırasıyla; İspanya, İtalya, Yunanistan, Türkiye, Tunus ve Fas yer almaktadır. Zeytinyağı üretimde, AB ülkelerinin payı yaklaşık \% 70 seviyelerindedir. Türkiye üretim alanı bakımından Dünya'da, 845,542 ha ile altıncı, üretim açısından 1,730,000 ton ile dördüncü sıradadır (FAO, 2018). Türkiye de zeytin yetiştiriciliği, Güneydoğu Anadolu'da Mardin'in güney kesimlerinden başlayarak, Akdeniz, Ege ve Marmara kıyı kesimleri ile alçak kesimleri takip ederek yer yer Karadeniz kıyılarında yayılım göstermektedir (Koca, 2004). Ülkemizde, Ege bölgesi yetiştiriciliğinin en yoğun olarak yapıldığı bölge konumundadır. Zeytin üretiminde öncelikli iller arasında; Aydın (259,237 ton), İzmir (229,510 ton), Muğla (190,641 ton), Manisa (183,610 ton), Balıkesir (181,022 ton), Mersin (143,275 ton) ve Hatay (135,900 ton) yer almaktadır (TUIKK, 2016).

Zeytin üretimi mevcut tarımsal alanlar içinde arazi yapılarına göre 3 ana guruba ayrılabilir. Bu kapsamda; (1) yoğun tarımsal faaliyetlerin ve sulu tarımın yapıldığı düz ve düze yakın alanlar, (2) yarı yoğunlukta tarımsal üretimin gerçekleştiği eğimli alanlar ve (3) geleneksel üretimin yapıldığı teras ve marjinal alanlar yer almaktadır (Beaufoy, 1998; Guzman Alvarez, 1999). Düşük arazi uygunluğu nedeniyle, tarımsal amaçlar için uygun görülmeyen marjinal zeytin alanları, çevre yönetimi ve koruma alanlarında (biyolojik çeşitlilik, yangın kontrol bölgeleri, erozyon kontrolü, vb.) önemli rol oynayabilir (Guzman-Alvarez and Navarro-Cerrillo, 2008).

Türkiye iklim, arazi yapısı, toprak ve bitki türlerinin dağılımları açısından büyük çeşitliliğe sahip olması sebebiyle birçok mikro ve makro iklim bölgelerine sahiptir. İklimdeki bu farklılığa bağlı olarak yağış ve sıcaklık parametreleri bölgesel olarak büyük değişim göstermektedir. Zeytin yetiştiriciliğinde alansal sınırları belirlenmesine etki eden en önemli faktör iklimdir. İklim faktörleri arasında ise sıcaklık en belirleyici faktördür. Sıcaklık değerinin düşük, yüksek ve ekstrem değerleri zeytinin yetişmesini, kalitesini ve verimini olumsuz şekilde etkilemektedir. Yıllık ve aylık sıcaklık ortalamaları, zeytin bitkisinin hem vejetatif ve hem de generatif gelişmesinde çok önemli rol oynamaktadır. Kışın sıcaklık düşüşleri farklı çeşitler için soğuklama intiyaçlarını karşılayacak seviyede olmalı fakat kalıcı zararların olabileceği aşırı soğuklardan kaçınılmalıdır. Zeytin dona karşı olukça hassas olması sebebiyle, düşük sıcaklıkların seviyelerine bağlı olarak zeytin ağaçlarında aşıı yaprak dökümü, kabuk çatlaması, ince ve kalın dallar da zararlar görülebilir (Temuçin, 1993; Efe ve ark., 2009; Ayaz ve Varol, 2015). İklimin fenolojik dönem süresince değişimi, ürünün gelişimine ve verimi belirleyen öğelere etkisi büyüktür. Özellikle, çiçeklenme döneminde sıcaklık önemli bir rol oynamaktadır. Bu dönemde, çiçeklenme yoğunluğu verimin önemli bir göstergesidir. (Oteros et al., 2013; Orlandi et al., 2010; Galan et al., 2008).

Akdeniz iklimine oldukça iyi uyum sağlayan zeytin, Akdeniz Havzasında genel olarak yağışa dayalı olarak yetiştirilmektedir. Verimli zeytincilik için yıllık yağışın $600 \mathrm{~mm}$ den fazla olması gerekir (Gucci and Fereres, 2012). İlkbaharda toprakta yeterli nemin olması, çiçek oluşumunu ve dane tutum oranını arttırmaktadır. Ayrıca, meyvede iyi bir gelişimin olması ve yağ oluşumu elde edilmesinde yeterli suyun sağlanması gerekir (Brito et al., 2019). Zeytin yetiştiriciliğinde toprak özellikleri ürünün verim ve kalitesini etki etmektedir. Bu kapsamda; toprak reaksiyonu, tuzluluk, organik madde, kireç, toprağın su tutma kapasitesi, makro ve mikro besin elementleri büyük önem taşımaktadır. Topoğrafik yapı bitkinin fenolojik gelişiminde önemli bir rol oynamaktadır (García-Mozo et al., 2006; Aguilera and Ruíz-Valenzuela, 2009). Akdeniz iklim kuşağında hidrolojik değişkenlik; düzensiz topoğrafya, denize uzaklık ve yağışın etkisi altındadır (Sofo et al., 2008). Akdeniz havzasında, zeytin ağaçları eğimli alanlar ve tepeliklerde yoğun bir şekilde görülür. Zeytin yetiştiriciliğinde, 800 metreden daha yüksek yerlerde ekonomik açıdan ürün alınması uygun değildir. Özellikle soğuk bölgelerde don ve kar tehlikesi olabildiği gibi gelişme periyodu süresi kısadır (Therios, 2009). 
Tarımsal üretimin ve verimliliğin artııılması için günümüzde hızla değişen pazar koşulları ve çevresel etkiler, tarımsal planlanmanın doğru yapılmasını zorunlu kılmaktadır. Arazilerden optimum yararlanılması için ürünün ekolojik gereksiniminin o bölgedeki ekolojik yapı içerisinde ne oranda karşılanabildiğinin belirlenmesi gerekir (FAO, 1976). Bu değerlendirmelerin yapılmasında arazi uygunluk analizleri yaygın olarak kullanılmaktadır (FAO, 1985; Rossiter, 1996). Arazinin fiziksel koşullarına göre yapılan uygunluk sınıflaması ile ürünün yetiştirilebileceği potansiyel alanlar belirlenerek sürdürülebilir tarımsal üretim için mevcut arazi kaynaklarının optimum kullanılması sağlanmaktadır. Birçok faktörün etki ettiği mekansal uygunluk analizlerinde, değerlendirmeye alınan arazi kriterlerinin çok sayıda olması, yapılacak olan değerlendirmenin çok kriterli değerlendirme (ÇKD) yaklaşımı olarak ortaya çıkmasına neden olmaktadır (Malczewski, 1999). Amaç fonksiyonunun oluşmasında çok sayıda parametre hedef doğrultusunda bir karar verme problemi ortaya çıkarır. ÇKD modellerinin amacı kriterlerin değerlendirilmesinde çoklu alternatifler ile karar verme problemlerinin tanımlanarak çözüm bulunmasıdır (Jankowski, 1995). ÇKD'nin etkin kullanımıyla karar probleminin hiyerarşik bir yapı içerisinde ele alınması ile değerlendirme homojenlik kazanmakta ve problem daha küçük parçalara ayrılarak çözüm kolaylaştırımaktadır (Saaty and Vargas, 2001). Bununla birlikte amaç doğrultusunda her kriter farklı önemlilik derecelerine sahip olabilir. Analitik Hiyerarşi Süreci (AHS), problemi kendi içinde küçük parçalara ayırdıktan sonra, karşılaştırılan iki kriterin, aralarındaki önemini ve birbirlerine olan göreceli üstünlüklerini belirleyen bir yaklaşımdır (Saaty, 1980). Tarımsal üretimin farklı konularında AHS, karar verme yaklaşımı olarak kullanılmaktadır (Montazar and Behbahani, 2007; Günden ve Miran, 2008; Ayehu and Besufekad, 2015).

Çok sayıda kriterin bir arada ele alınarak yönetilmesi ile arazi uygunluk değerlendirmesinin yapılmasında, ÇKD yöntemi CBS teknikleri ile birleştirilerek kısa zamanda daha doğru kararların alınması sağlanmaktadır (Ceballos-Silva and Lopez-Blanco, 2003; Hossain and Das, 2010; Nzeyimana et al., 2014; Kazemi and Akinci, 2018). CBS'de farklı ekolojik kapsamların birleştirilmesinde ağırlıklandırılmış doğrusal kombinasyon (ADK) metodu kullanılmıştır. ADK yaklaşımında, önemlilik derecelerine göre göreceli olarak ağırlıklandırılmış kriterlerin birleştirilmesi sonucu ürün için arazinin uygunluğu sınıflandırılmaktadır (Malczewski, 2004, Drobne and Lisec, 2009).

$\mathrm{Bu}$ çalışmada, zeytin yetiştiriciliğinde ekolojik istekleri dikkate alınarak, iklim, toprak ve topoğrafik parametrelere göre CBS destekli ÇKD analizi tekniği kullanılarak, Türkiye de zeytin üretimi açısından uygun potansiyel alanlar belirlenmiştir. Arazi uygunluk modelinin ana aşamalarını; veri tabanlarının hazırlanması, veri katmanlarının oluşturulması, ÇKD prosüdürünün uygulanması ve CBS'de modellenmesi oluşturmaktadır.

\section{MATERYAL ve YÖNTEM}

\section{Çalışma alanı}

Türkiye, kuzey yarımkürede $36^{\circ}-42^{\circ}$ kuzey paralelleri ve $26^{\circ}-45^{\circ}$ doğu meridyenleri arasında yer alır ve toplam yüzölçümü yaklaşık 783,000 km²,dir. Türkiye'de ortalama yükseklik 1132 m'dir. Yükselti batıdan doğuya doğru gidildikçe artmakta ve Doğu Anadolu'da 2000 m'nin üzerine çıkmaktadır. Ülkesel olarak çok farklı topoğrafik yapının bulunması, dağların uzanış yönü ve üç tarafının denizlerle çevrili olması sebebiyle iklimsel farklılıklar fazladır. Türkiye'de yıllık ortalama sıcaklık $13.5^{\circ} \mathrm{C}$ 'dir. Ortalama sıcaklık normal koşullarda Ocak ayında minimum ve Temmuz ayında maksimum değerleri almaktadır. Yıllık yağış ortalaması 574 mm ve yağış rejimi 250 mm'den 2230 mm'ye kadar değişmektedir. Türkiye'de yağışın dağııımı hem alansal hem de zamansal olarak çok değişkenlik gösterir. Akdeniz Bölgesi yağışının çoğunu kışın alırken, Doğu ve G. Doğu Anadolu ilkbaharda alır. Karadeniz Bölgesi ise her mevsim yağışlıdır (MGM, 2019).

\section{Veri kaynakları}

Meteorolojik parametrelerin elde edilmesinde; Meteroloji Genel Müdürlüğü tarafından üretilen, 1975-2015 yılları arasında Türkiye'nin tamamını kapsayan 264 adet meteorolojik istasyona ait uzun yıllar günlük iklim verileri kullanılmıştır. İklim verilerinden minimum, maksimum, ortalama sıcaklıklar ile yağış verileri günlük veri formatından istasyon bazında aylık ortalama verilere dönüştürülmüştür. Meteorolojik istasyonlara ait uzun yıllar aylık ortalamaları içeren noktasal bazlı iklim verileri ile yükseklik verisi entegre 
edilmiştir. Bu amaçla Hutchinson'un (1995) "thin-plate smoothing spline" enterpolasyon tekniği ve ANUSPLIN yazılımı (Hutchinson, 2000) kullanılmıştır. Bu teknikte, hücresel bazda rastgele dağılmış noktasal veriler yükseklik faktörü de dikkate alınarak alana yayılmakta ve her hücrenin sayısal değeri istatistiki bir yaklaşımla tahmin edilmektedir. İklim yüzey haritaları, CLIMAP (Pertziger and De Pauw, 2002) programı aracılığıyla katman olarak elde edilmiş ve CBS ortamında altık parametre haritaları üretilmiştir. Toprak verileri, Mülga Topraksu Genel Müdürlüğü tarafından, 1966-1971 yılları arasında tüm ülke topraklarının toprak etüd çalışmaları ile altlık veri olarak 1:25.000 ölçekli topoğrafik haritalar kullanılarak oluşturulan ülkesel ölçekte sayısal toprak veri tabanı kullanıımıştır. Topoğrafik yapının analizinde kullanılan eğim ve yükseklik katmanları, 90 metre çözünürlüklü SRTM (Space Radar Topography Mission) Sayısal Yükseklik Modeli (SYM) verisi kullanılarak üretilmiştir. Çalışma kapsamında yapılan CBS model ve analizlerinde, ArcGIS 10.4 programı (ESRI, 2011) kullanılmıştır.

\section{Yöntem}

Zeytin yetiştirilmesine uygun potansiyel alanların belirlenmesinde, ürünün gelişme döneminde etkili olan kriterler belirlenerek CBS teknikleri temelinde çoklu kriter değerlendirme yöntemi uygulanmıştır (FAO, 1976; FAO, 1985). Arazi uygunluk değerlendirmesi 5 ana aşamadan oluşmaktadır. Bu aşamalar; (1) Hiyerarşik yapının oluşturulması, (2) Kriterlerin sınıflandırılması, (3) İkili karşılaştırma matrisi oluşturulması, (4) Kriterlerin ağırlıklandırılması ve matris tutarlıı̆ının hesaplanması, (5) ürün uygunluk sınıflarının oluşturulmasıdır (Şekil 1).

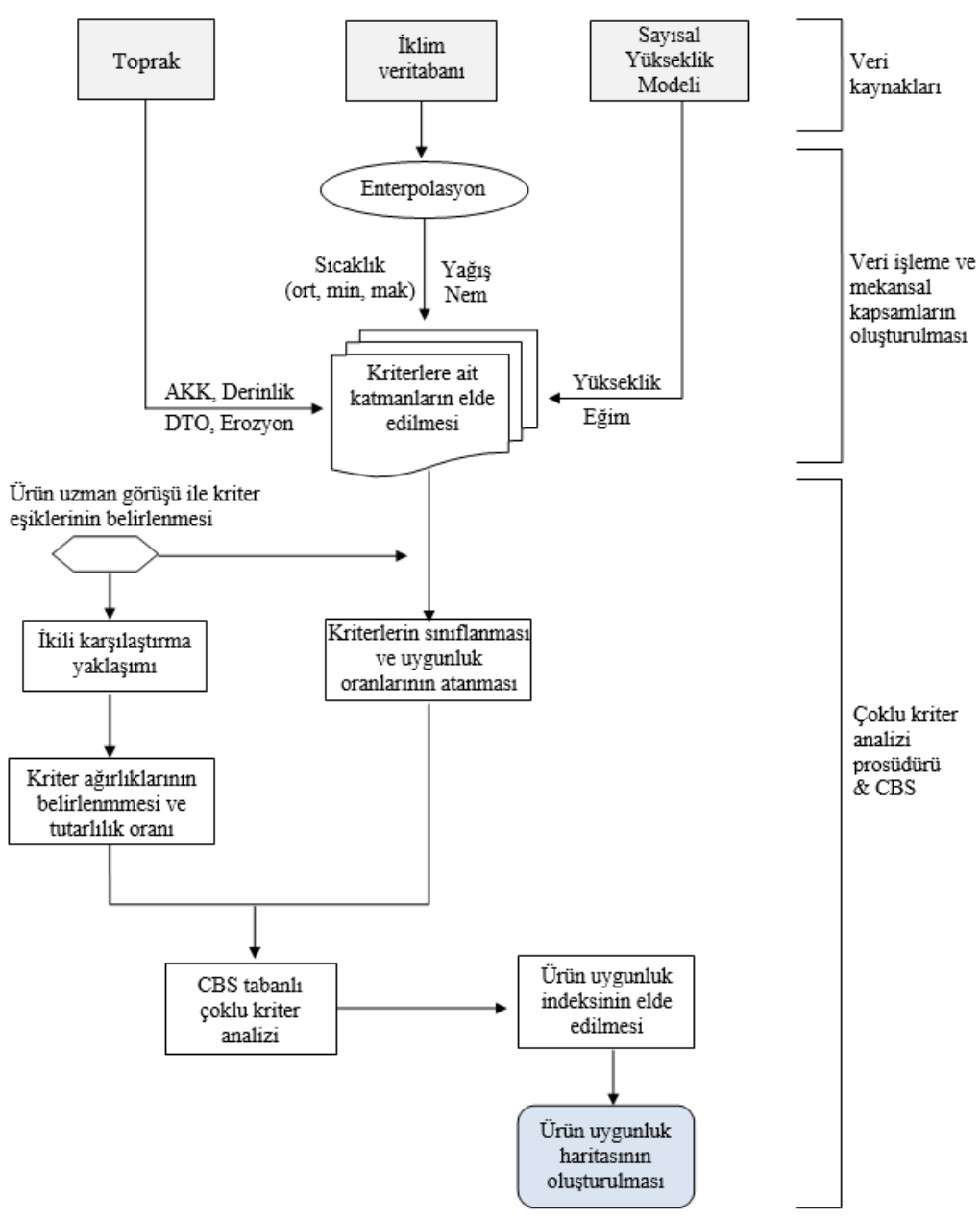

Şekil 1. CBS tabanlı çoklu kriter karar verme yöntemi.

Figure 1. GIS-based multi-criterion decision making method. 


\section{Hiyerarşik yapının oluşturulması}

Bir hiyerarşik model yapısı; amaç, kriter, alt kriter ve alternatiflerden oluşmaktadır. Başlangıç aşamasında, karar verme problemi tanımlanır. Karar verme probleminin tanımlanmasında karar noktalarını etkileyen kriterler ve kriterler ile ilişkili olan alt kriterler belirlenir. Model yapısı oluştururken ana kriterler olarak iklim ve topoğrafya belirlenmiştir. Ürünün yetişme dönemi boyunca gelişimine etkili olan ekolojik kriterler, modelin alt kriterlerini oluşturmaktadır. Bu kapsamda; yıllık ortalama sıcaklık $\left(\mathrm{C}_{1}\right)$, Ocak ayı ortalama sıcaklık $\left(\mathrm{C}_{2}\right)$, Ocak ayı mutlak minimum sıcaklık $\left(\mathrm{C}_{3}\right)$, Mayıs ayı ortalama sıcaklık $\left(\mathrm{C}_{4}\right)$, yıllık yağış toplamı $\left(\mathrm{C}_{5}\right)$, yaz dönemi ortalama maksimum sıcaklık $\left(\mathrm{C}_{6}\right)$, nispi nem $\left(\mathrm{C}_{7}\right)$, arazi kullanım kabiliyeti sınıfları $\left(S_{1}\right)$, toprak derinliği $\left(S_{2}\right)$, kısıtlayıcı toprak özellikleri $(K T O)\left(S_{3}\right)$, erozyon $\left(S_{4}\right)$, yükseklik $\left(T_{1}\right)$ ve eğim $\left(T_{2}\right)$ kriterleri değerlendirilmiştir. Alternatifler, uygunluk sınıflarını göstermektedir.

\section{Kriterlerin sınıflandırılması}

Ürünün yetişmesinde etkili olan alt kriterlere ait uygunluk sınıfları belirlenmiştir. Bu sınıflama içerisinde; uygun (S1), orta uygun (S2), az uygun (S3) ve uygun değil (N) olarak değerlendirilmiştir. Zeytin ağacının yetişme şartlarının belirlenmesinde fenolojik dönemler dikkate alınarak parametre seçimi ve eşik değerleri uzman görüşü ve literatür (Sys, 1993; Shalaby, 2006; Guo, 2010; Brito, 2019) bilgileri ile belirlenmiştir (Çizelge 1).

Çizelge 1. Parametrelerin uygunluk sınıfları ve sınır değerleri

Table 1. Suitability classes and limit values of parameters

\begin{tabular}{|c|c|c|c|c|c|c|}
\hline \multirow[b]{2}{*}{ Ana kriter } & \multirow[b]{2}{*}{ Alt kriter } & \multicolumn{4}{|c|}{ Uygunluk sınıfları ve değerleri } & \multirow[b]{2}{*}{$\begin{array}{l}\text { Uygun değil } \\
\text { (N) }\end{array}$} \\
\hline & & Birim & $\begin{array}{l}\text { Uygun } \\
\text { (S1) }\end{array}$ & $\begin{array}{l}\text { Orta uygun } \\
\text { (S2) }\end{array}$ & $\begin{array}{c}\text { Az uygun } \\
\text { (S3) }\end{array}$ & \\
\hline \multirow{7}{*}{ İklim (C) } & Yıllık ort. sıc. $\left(\mathrm{C}_{2}\right)$ & $\left({ }^{\circ} \mathrm{C}\right)$ & $20-15$ & $15-14$ & $14-13$ & $<13$ \\
\hline & Ocak ayı mutlak min. sıcaklık $\left(\mathrm{C}_{2}\right)$ & $\left({ }^{\circ} \mathrm{C}\right)$ & $2-(-4)$ & $\begin{array}{c}-4-(-6) \\
2-4\end{array}$ & $\begin{array}{c}-6-(-7.5) \\
4-6\end{array}$ & $\begin{array}{c}<-7.5 \\
>6\end{array}$ \\
\hline & Ocak ayı ort. sıcaklık $\left(\mathrm{C}_{3}\right)$ & $\left({ }^{\circ} \mathrm{C}\right)$ & $6-10.5$ & $\begin{array}{c}10.5-12 \\
6-5\end{array}$ & $\begin{array}{c}12-13 \\
5-4\end{array}$ & $\begin{array}{l}>13 \\
<4\end{array}$ \\
\hline & Mayıs ayı ort. sıcaklık $\left(C_{4}\right)$ & $\left({ }^{\circ} \mathrm{C}\right)$ & $18-23$ & $\begin{array}{l}23-26 \\
18-17\end{array}$ & $\begin{array}{l}26-30 \\
17-16 \\
\end{array}$ & $>30$ \\
\hline & Yıllık yağış toplamı $\left(\mathrm{C}_{5}\right)$ & $(\mathrm{mm})$ & $600-1100$ & $\begin{array}{c}600-400 \\
1100-1200\end{array}$ & $\begin{array}{c}400-300 \\
1200-1400\end{array}$ & $\begin{array}{l}<300 \\
>1400\end{array}$ \\
\hline & Yaz dönemi ort. mak. sıcaklık $\left(\mathrm{C}_{6}\right)$ & $\left({ }^{\circ} \mathrm{C}\right)$ & $24-30$ & $\begin{array}{l}30-34 \\
24-23\end{array}$ & $\begin{array}{l}34-36 \\
23-22\end{array}$ & $\begin{array}{l}>36 \\
<22\end{array}$ \\
\hline & $\operatorname{Nem}\left(C_{7}\right)$ & $(\%)$ & $60-70$ & $\begin{array}{l}70-75 \\
55-60 \\
\end{array}$ & $\begin{array}{l}75-85 \\
55-40 \\
\end{array}$ & $\begin{array}{l}>85 \\
<40 \\
\end{array}$ \\
\hline \multirow{4}{*}{ Toprak (S) } & $\operatorname{AKK}\left(S_{1}\right)$ & Sınıf & I, II, III & IV & VI, VII & VIII \\
\hline & Derinlik $\left(\mathrm{S}_{2}\right)$ & Sinıf & Derin & Orta & Sığ & Çok sığ \\
\hline & $\mathrm{KTO}\left(\mathrm{S}_{3}\right)$ & Sinıf & Yok, Hafif & Orta & Ciddi & Çok ciddi \\
\hline & Erozyon $\left(\mathrm{S}_{4}\right)$ & Sınıf & Yok, Hafif & Orta & Şiddetli & Çok şiddetli \\
\hline \multirow{2}{*}{ Topoğrafya $(T)$} & Yükseklik $\left(T_{1}\right)$ & $(\mathrm{m})$ & $0-550$ & $550-650$ & $650-800$ & $>800$ \\
\hline & Eğim $\left(T_{2}\right)$ & (\%) & $<10$ & $10-20$ & $20-35$ & $>35$ \\
\hline
\end{tabular}

\section{İkili karşılaştırma matrisinin oluşturulması}

Kriterin birbirlerine göre göreceli önemlilik düzeyleri belirlenerek kriter ağırlıklandırılmasında Analitik Hiyerarşi Süreci (AHS) tekniği kullanılmıştır (Saaty, 1980). Kriterler arasındaki karşılaştırma matrisi, $n x n$ boyutlu bir kare matrisini oluşturur. Karşılaştırma matrisinin köşegeni üzerindeki bileşenler, i=j olduğunda 1 değerini alır. Bu durumda ilgili faktör kendisi ile karşılaştırımaktadır. Faktörlerin karşılaştırıması, birbirlerine göre sahip oldukları önem değerlerine göre 1 ila 9 arasında değer atanarak yapılır. Birinci faktör üçüncü faktöre göre daha önemli ise bu durumda karşılaştırma matrisinin birinci satır üçüncü sütun bileşeni ( $i=1, j=3$ ) 3 değerini, tersi durum da ise $1 / 3$ değerini almaktadır (Şekil 2). Faktörlerin birebir karşılıklı karşılaştırılmasında Çizelge 2'deki önem skalası kullanılmıştır (Saaty, 1980). 
Şekil 2. Karşılaştırma matrisi.

$$
A=\left[\begin{array}{cccc}
a_{11} & a_{12} & \ldots & a_{1 n} \\
a_{21} & a_{22} & \ldots & a_{2 n} \\
\cdot & & & \cdot \\
\cdot & & & \cdot \\
\cdot & & & \cdot \\
a_{n 1} & a_{n 2} & \ldots & a_{n n}
\end{array}\right]
$$

Figure 2. Comparison matrix.

Çizelge 2. İkili karşılaştırma skalası

Table 2. Binary comparison scale

\begin{tabular}{cl}
\hline Önem Değeri & Değer Tanımları \\
\hline 1 & Her iki faktörün eşit öneme sahip olması \\
3 & 1. Faktörün 2. faktörden daha önemli olması \\
5 & 1. Faktörün 2. faktörden çok önemli olması \\
7 & 1. Faktörün 2. faktörden çok güçlü öneme sahip olması \\
9 & 1. Faktörün 2. faktörden mutlak üstün öneme sahip olması \\
\hline $2,4,6,8$ & Ara değerler \\
\hline
\end{tabular}

\section{Kriterlerin ağırlıklandırılması ve matris tutarlılığının hesaplanması}

Kriterlerin ağırlıklandırılmasında ikili karşılaştırma matrisi normalize edilmektedir. Matrisin her element değeri sütun toplamına oranlanır. Oluşan matrisin satır elementlerinin toplamının element sayısına bölünmesiyle ağırlık oranları hesaplanmaktadır. Ağırlıklar, 0-1 arasında değer alır ve toplamları 1'e eşittir. (Malczewski, 1999). Karar vericinin faktörler arasında yaptığı bire bir karşılaştırmadaki tutarlılığın ölçülebilmesinde tutarlılık oranı (TO) aşağıdaki eşitlikle hesaplanmaktadır (Saaty, 1980).

$\mathrm{TO}=\mathrm{T} \mathbf{i} / \mathrm{R} \mathbf{i}$,

$\mathrm{Ti}=\left(\lambda_{\text {mak }}-\mathrm{n}\right) /(\mathrm{n}-1)$

Eşitlikte; Ti: tutarlılık indeksini, $\lambda$ : maksimum özvektör değerini, $n$ : kriter sayısını, $R i$ : rastgele indeksi (rastgele üretilmiş ikili karşılaştırmalar matrisinin tutarılıı indeksi) göstermektedir (Çizelge 3).

Çizelge 3. Rastgele indeks değerleri (RI) (Saaty, 1980)

Table 3. Random index values

\begin{tabular}{lllccccccccc}
\hline $\mathbf{n}$ & 1 & 2 & 3 & 4 & 5 & 6 & 7 & 8 & 9 & 10 & 11 \\
\hline $\mathbf{R i}$ & 0 & 0 & 0.58 & 0.9 & 1.12 & 1.24 & 1.32 & 1.41 & 1.45 & 1.49 & 1.51 \\
\hline
\end{tabular}

TO değeri AHS tekniğinde kararın oluşturulmasında tutarııı̆ın bir ölçüsü olarak kullanılmaktadır. TO değerinin 0.10 'dan küçük olması karar vericinin değerlendirmeye aldığı arazi özellikleri ile ilgili karşılaştırmaların tutarlı olduğunu ve arazi uygunluk değerlendirme modelinde göreceli ağırlıkların uygun şekilde seçildiğini gösterir. TO değerinin 0.10'dan büyük olması, AHS'deki bir hesaplama hatasını veya karar vericinin karşılaştırmalarındaki tutarsızlığını gösterir (Brunelli, 2014; Liu et al., 2017).

\section{Ürün uygunluk sınıflarının oluşturulması}

Kriter ve alt kriterlere ait uygunluk sınıfları için 0-1 arasında standardize edilmiş sınıf değeri atanır. Önem derecelerine göre belirlenen kriter ağırlıkları ile sınıf değerleri çarpılarak uygunluk değeri belirlenir. Ürün uygunluk haritası, hücresel (raster) veri formatında ve $90 \mathrm{~m}$ mekânsal çözünürlükte üretilmiştir. Uygunluk haritasına ait bir hücrenin uygunluk değeri 0-1 arasındaki indeks değerinden oluşur. Bu değerin 
1 olması parametrenin mekansal bazda uygun olduğunu, 0 değeri ise uygun olmadığını göstermektedir. Uygunluk haritasının oluşturulmasında tüm tematik katmanlar ağırlıklı doğrusal kombinasyon modeli kullanılarak CBS ile entegre edilmiştir. Kriter katmanlarının birleştirilmesinde ArcGIS programı kullanılarak aşağıdaki formül temelinde uygulanmıştır (Eastman, 1995; Drobne et al., 2009).

$\mathrm{n}$

$$
\mathrm{S}=\sum_{\mathrm{i}=1} w_{i} x_{i} \quad\left(i=1,2,3, \ldots, n ; \sum w_{i}=1 ; w_{i}>0\right)
$$

Eşitlikte; $\mathrm{S}=$ Uygunluk değeri, $w_{i}=$ i'ninci faktör ağırlı̆̆ı, $x_{i}=$ i'ninci faktörün sınıf değeri, $\mathrm{n}=$ toplam faktör sayısı'dır.

CBS tabanlı ÇKD yöntemine göre üretilen uygunluk haritası; çok uygun, orta uygun, az uygun ve uygun olmayan olarak 4 sınıfa ayrılmıştır. Bu sınıflar; çok uygun (S1), ürünün yetişmesine sınırlayıcı fiziksel bir şartın olmadığı veya hafif kısıtların olduğu alanları; orta derece uygun (S2), bazı sınırlamaların olduğunu ve verimde düşüşlerin olabileceği üretim alanları; az uygun (S3), ciddi fiziksel sınırlamaların olduğu marjinal alanları; uygun olmayan sınıf $(N)$ ise üretimin yapılamasını engelleyici çok ciddi sınırlamaların olduğu üretim yapıımasının mümkün olmadığı alanlardır.

\section{ARAŞTIRMA BULGULARI ve TARTIŞMA}

$\mathrm{Bu}$ çalışmada; iklim ve topoğrafik kriterlere göre zeytin yetiştirilmesine uygun alanların belirlenmesinde Çok Kriterli Değerlendirme (ÇKD) tekniği kullanılmıştır. Bu değerlendirme yaklaşımında, ürünün gelişim dönemleri dikkate alınarak etkili olan kriter, alt kriter ve sınıf eşik değerleri belirlenmiştir. Alt kriterler kendi içinde çok uygun, orta uygun, az uygun, uygun değil olarak sınıflandırılmıştır. Ana kriter ve alt kriter haritaları iklim (Şekil 3), toprak ve topoğrafik (Şekil 4) parametreler için raster veri formatında üretilmiştir.

Zeytin yetiştiriciliğinde etkili olan ekolojik kriter ağırlıkları AHS tekniğine göre belirlenmiştir. Ana kriter ağırlıkları içinde 0.640 ağırlık değeriyle iklim en yüksek ağılığa sahiptir. Diğer ana kriterlerden toprağın ağırlığı 0.240 ve topoğrafyanın ağırlığı ise 0.120 düzeyindedir. İklim ana katmanı kapsamında ele alınan kriterler arasında, yıllık ortalama sıcaklık (0.339) en yüksek ağırlığa sahiptir. Bu kriteri; Ocak ayı ortalama sıcaklık (0.238) ve mutlak minimum sıcaklık (0.193) takip etmiştir (Çizelge 4). Toprak ana katmanı içerisinde yer alan AKK, 0.404 ağırlık oranı ile en yüksek ağırlığa sahiptir. Bu kriteri, derinlik (0.330) ve KTO (0.198) izlemiştir. Diğer bir ana kriter olan topoğrafik ana katmanı altında yer alan yükseklik kriteri 0.550 ve eğim kriteri ise 0.450 ağırlık düzeyindedir. Toplam kriter ağırlıkları arasında yıllık ortalama sıcaklık (0.217) en yüksek toplam kriter ağılığına sahiptir. Bu kriteri; Ocak ortalama sıcaklık (0.152) ve mutlak minimum sıcaklık (0.124) izlemiştir (Çizelge 5).

Çizelge 4. Alt kriterlerin ikili karşılaştırma matrisi

\begin{tabular}{|c|c|c|c|c|c|c|c|c|}
\hline & $C_{1}$ & $C_{2}$ & $C_{3}$ & $C_{4}$ & $C_{5}$ & $C_{6}$ & $C_{7}$ & $\begin{array}{c}\text { Normalize } \\
\text { Ağırlık }\end{array}$ \\
\hline$C_{1}$ & 1.000 & & & & & & & 0.339 \\
\hline$C_{2}$ & 0.500 & 1.000 & & & & & & 0.238 \\
\hline$C_{3}$ & 0.500 & 0.667 & 1.000 & & & & & 0.193 \\
\hline $\mathrm{C}_{4}$ & 0.250 & 0.250 & 0.333 & 1.000 & & & & 0.083 \\
\hline$C_{5}$ & 0.250 & 0.250 & 0.333 & 0.500 & 1.000 & & & 0.068 \\
\hline$C_{6}$ & 0.167 & 0.200 & 0.200 & 0.500 & 0.500 & 1.000 & & 0.049 \\
\hline$C_{7}$ & 0.143 & 0.217 & 0.167 & 0.333 & 0.333 & 0.333 & 1.000 & 0.030 \\
\hline \multicolumn{8}{|c|}{$\lambda_{\text {mak: }}$ 7.241, RI: 1.32, TO: 0.03} & $\Sigma=1$ \\
\hline
\end{tabular}

Table 4. Binary comparison matrix of sub-criteria 
Çizelge 5. AHS tekniği ile ana, alt ve toplam kriter ağırlıkları

Table 5. Main, sub and total criteria weights with AHS technique

\begin{tabular}{|c|c|c|c|c|}
\hline Ana Kriter & $\begin{array}{l}\text { Ana Kriter } \\
\text { Ağırığı }\end{array}$ & Alt Kriter & $\begin{array}{l}\text { Alt Kriter } \\
\text { Ağırlığı }\end{array}$ & $\begin{array}{c}\text { Toplam Kriter } \\
\text { Ağırlığı }\end{array}$ \\
\hline \multirow{7}{*}{ İklim (C) } & \multirow{7}{*}{0.640} & Yıllık ortalama sıcaklık $\left(C_{1}\right)$ & 0.339 & 0.217 \\
\hline & & Ocak ayı ort. sıcaklık $\left(C_{2}\right)$ & 0.238 & 0.152 \\
\hline & & Mutlak minimum sıcaklık $\left(C_{3}\right)$ & 0.193 & 0.124 \\
\hline & & Mayıs ayı ort. sıcaklık $\left(C_{4}\right)$ & 0.083 & 0.053 \\
\hline & & Yıllık yağış toplamı $\left(C_{5}\right)$ & 0.068 & 0.044 \\
\hline & & Yaz dönemi mak. sıcaklık $\left(C_{6}\right)$ & 0.049 & 0.031 \\
\hline & & $\operatorname{Nem}\left(C_{7}\right)$ & 0.030 & 0.019 \\
\hline \multirow{4}{*}{ Toprak (S) } & \multirow{4}{*}{0.240} & $\operatorname{AKK}\left(S_{1}\right)$ & 0.404 & 0.097 \\
\hline & & Derinlik $\left(S_{2}\right)$ & 0.330 & 0.079 \\
\hline & & $\mathrm{KTO}\left(\mathrm{S}_{3}\right)$ & 0.198 & 0.048 \\
\hline & & Erozyon $\left(S_{4}\right)$ & 0.067 & 0.016 \\
\hline \multirow{2}{*}{ Topoğrafya $(\mathrm{T})$} & \multirow{2}{*}{0.120} & Yükseklik $\left(T_{1}\right)$ & 0.550 & 0.066 \\
\hline & & Eğim $\left(T_{2}\right)$ & 0.450 & 0.054 \\
\hline
\end{tabular}

Zeytin yetiştiriciliğinin yoğun olarak yapıldığı bazı önemli alanlarda uzun yıllara ait meteorolojik istasyon verileri bulunmadığı için ülkesel düzeyde mevcut iklim verileri alana yayılarak (enterpolasyon) iklim verileri üretilmiştir. Zeytin üretim alanlarına ait optimum değerlerin belirlenmesinde üretilen uygunluk haritası temel alınmıştır. İdari sınırlar içinde yer alan zeytin yetiştiriciliğine çok uygun alanlar dikkate alınmıştır. Zeytin üretiminin yoğun olarak yapıldığı bazı ilçelere ait ortalama değerleri Çizelge 6'da verilmiştir.

Çizelge 6. İlçelere göre zeytin yetiştiriciliğine uygun alanların iklim ve yükselti değerleri

Table 6. Climate and elevation values of suitable areas for olive cultivation by districts

\begin{tabular}{lcccccccc}
\hline Lokasyon & $\begin{array}{c}\text { Yıllık ort. } \\
\text { Sıc. }\left({ }^{\circ} \mathrm{C}\right)\end{array}$ & $\begin{array}{c}\text { Ocak ort. } \\
\text { Sıc. }\left({ }^{\circ} \mathrm{C}\right)\end{array}$ & $\begin{array}{c}\text { Mutlak min. } \\
\text { Sıc. }\left({ }^{\circ} \mathrm{C}\right)\end{array}$ & $\begin{array}{c}\text { Mayıs ort. } \\
\text { Sıc. }\left({ }^{\circ} \mathrm{C}\right)\end{array}$ & $\begin{array}{c}\text { Temmuz ort. } \\
\text { Sıc. }\left({ }^{\circ} \mathrm{C}\right)\end{array}$ & $\begin{array}{c}\text { Nem } \\
(\%)\end{array}$ & $\begin{array}{c}\text { Yağıs } \\
(\mathrm{mm})\end{array}$ & Yükselti (m) \\
\hline Akhisar & 15.8 & 5.8 & -4.6 & 19.4 & 26.9 & 63.0 & 576.8 & 156.8 \\
\hline Altınözü & 17.6 & 7.5 & -1.9 & 20.5 & 26.7 & 67.6 & 887.4 & 353.8 \\
\hline Ayvacık & 15.2 & 6.5 & -2.9 & 18.0 & 25.2 & 70.9 & 631.2 & 174.3 \\
\hline Ayvalık & 16.2 & 7.3 & -2.2 & 19.1 & 26.3 & 67.8 & 625.0 & 82.2 \\
\hline Birecik & 17.6 & 5.6 & -4.6 & 21.3 & 31.0 & 56.9 & 380.5 & 446.5 \\
\hline Bodrum & 18.0 & 10.0 & 0.8 & 20.1 & 27.7 & 61.3 & 698.7 & 182.4 \\
\hline Burhaniye & 15.8 & 6.7 & -3.1 & 19.0 & 26.3 & 63.5 & 636.7 & 97.2 \\
\hline Çine & 16.6 & 7.1 & -3.2 & 19.7 & 27.6 & 61.5 & 679.1 & 295.0 \\
\hline Edremit & 15.7 & 6.7 & -3.0 & 18.9 & 26.2 & 64.2 & 645.9 & 76.6 \\
\hline Ezine & 15.2 & 6.5 & -2.9 & 17.9 & 25.2 & 72.2 & 616.1 & 106.9 \\
\hline Gemlik & 14.8 & 6.3 & -3.6 & 17.4 & 24.4 & 70.8 & 700.2 & 49.0 \\
\hline Kaş & 17.3 & 9.1 & -0.7 & 19.4 & 26.8 & 60.9 & 741.8 & 368.2 \\
\hline Milas & 17.2 & 8.6 & -1.2 & 19.7 & 27.6 & 61.7 & 726.8 & 274.2 \\
\hline Mudanya & 14.6 & 5.9 & -3.8 & 17.3 & 24.4 & 69.9 & 675.2 & 56.7 \\
\hline Mut & 17.5 & 7.1 & -2.6 & 20.7 & 28.7 & 59.1 & 421.0 & 317.6 \\
\hline Nizip & 17.4 & 5.5 & -4.6 & 21.1 & 30.4 & 57.3 & 397.1 & 484.9 \\
\hline Silopi & 19.0 & 6.0 & -3.8 & 22.7 & 33.4 & 51.4 & 661.9 & 451.0 \\
\hline Söke & 17.1 & 8.5 & -1.2 & 19.7 & 27.1 & 62.2 & 641.5 & 146.0 \\
\hline
\end{tabular}



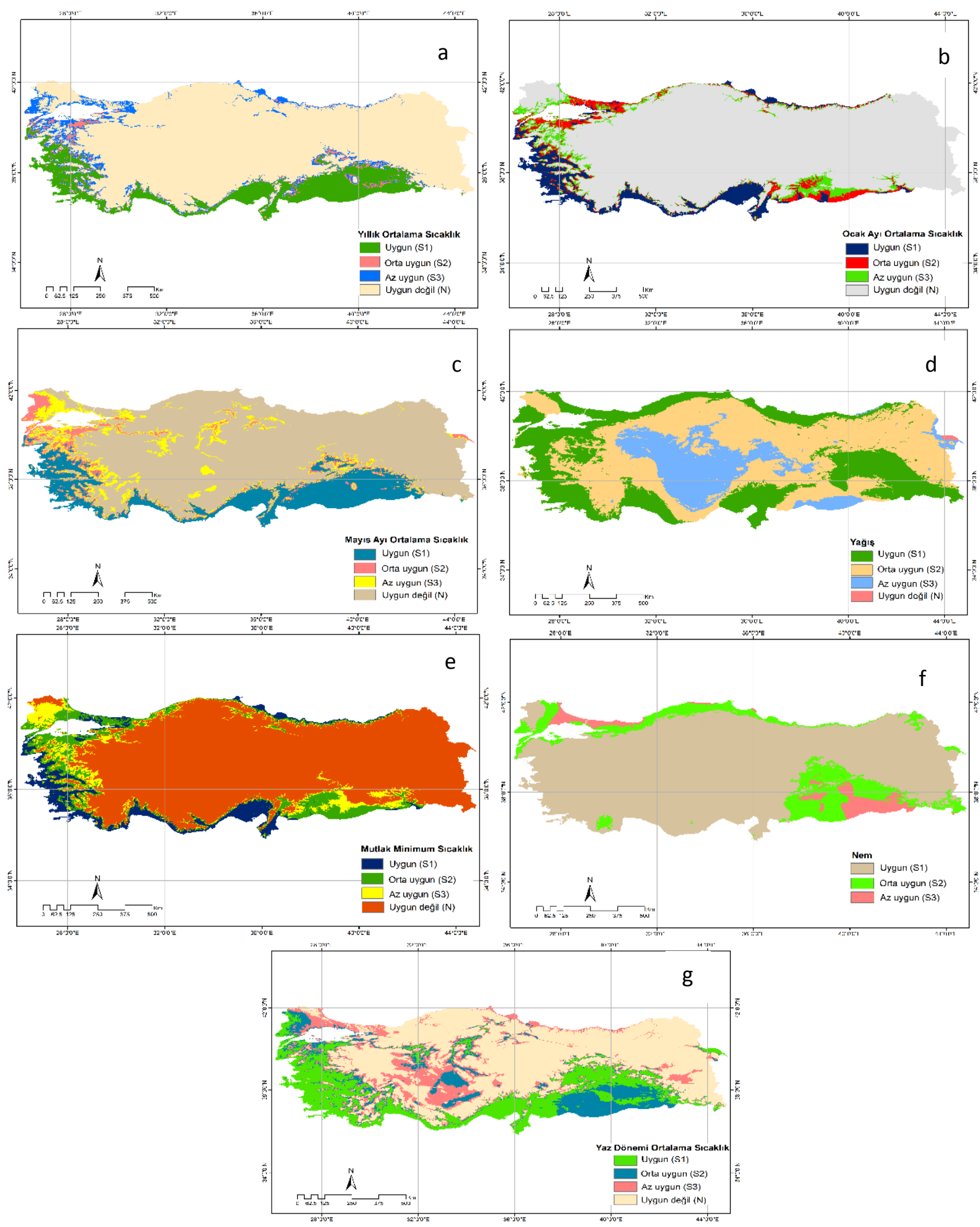

Şekil 3. İklim ana katmanına ait alt kriter haritaları; (a) yıllık ortalama sıcaklık, (b) Ocak ayı ortalama sıcaklık, (c) Mayıs ayı ortalama sıcaklık, (d) yağış, (e) mutlak minimum sıcaklık, (f) nem, (g) yaz dönemi ortalama sıcaklık.

Figure 3. Sub-criterion maps of the climate layer; (a) annual average temperature,(b) January average temperature, (c) May average temperature, (d) pricipitation, (e) absolute minimum temperature, (f) humidity, $(g)$ average summer maximum temperature. 

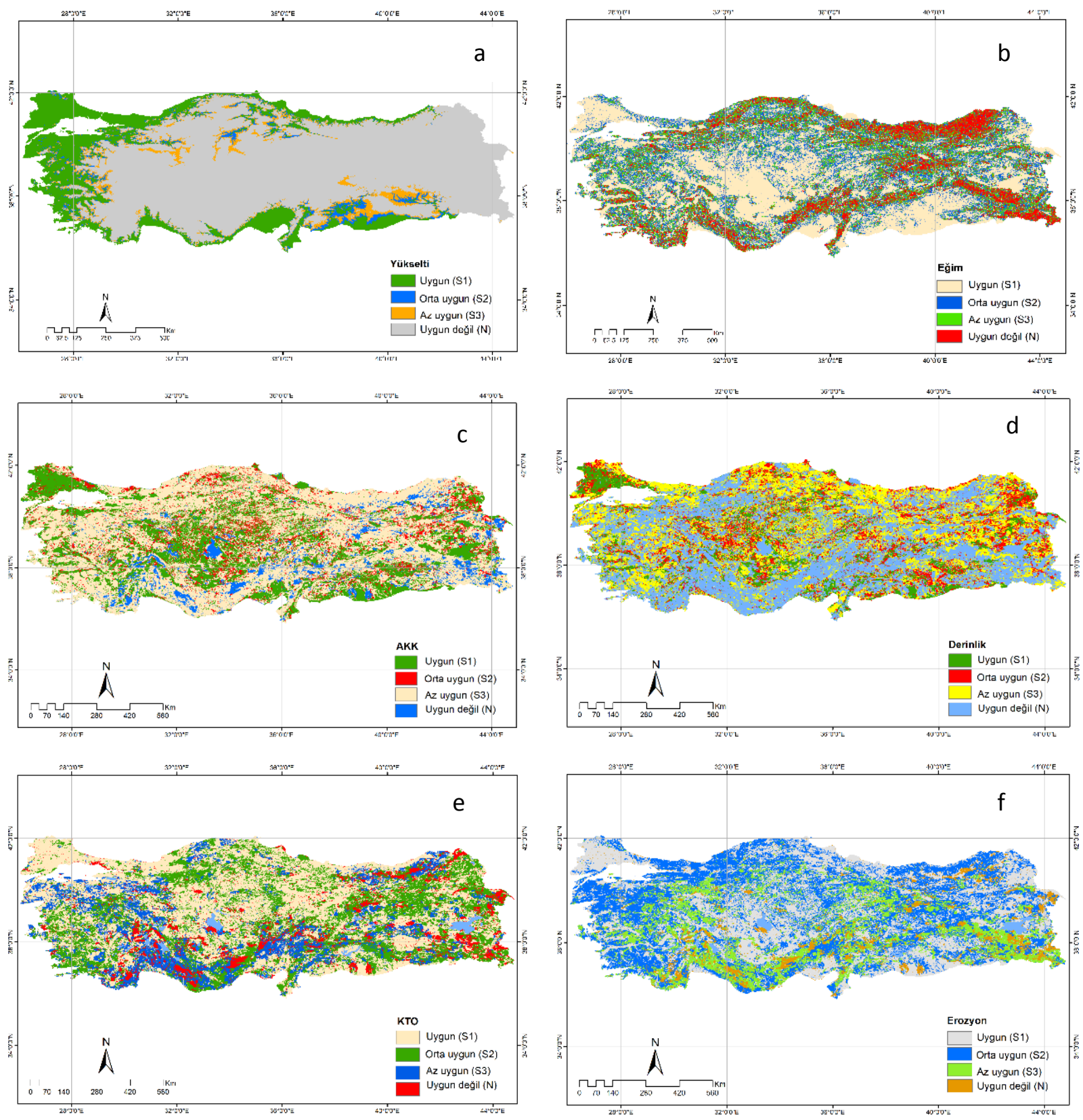

Şekil 4.Topoğrafik ve toprak ana katmanlarına ait alt kriter haritaları; (a) yükselti, (b) eğim, (c) arazi kullanım kabiliyeti sınıfları, (d) derinlik, (e) kısıtlayıcı toprak özellikleri, (f) erozyon.

Figure 4. Sub-criteria maps of soil and topographic layers; (a) altitude,(b) slope (c) land use capability sub-class, (d) soil depth, (e) restrictive soil properties, (f) erosion degree.

Sıcaklık, gerek zeytin ağacının coğrafi dağılımının sınıflandırılması gerekse gelişme dönemlerindeki etkisi nedeniyle büyük önem taşımaktadır (Bonofiglio, 2008). Zeytin ağacının sıcaklık gereksinimleri, fenolojik dönemlere göre farklılı göstermektedir. Sıcaklık parametreleri arasında gelişim dönemi içerisinde etkileri açısında ortalama sıcaklık, minimum sıcaklık ve maksimum sıcaklık parametreleri çalışma kapsamında incelenmiştir. Zeytin yetişen alanlarda, yıllık ortalama sıcaklığın $14,5^{\circ} \mathrm{C}$ civarı zeytin üretimi için alt sınır olarak kabul edilebilir (Ayaz ve Varol, 2015). Efe ve ark. (2009) tarafından yapılan çalışmada, Türkiye'de zeytin üretiminin yoğun olarak yapıldığı; Gemlik, Edremit, Milas, 
Antalya, Antakya ve Nizip istasyonları için yıllık ortalama sıcaklığın $14,9^{\circ} \mathrm{C}$ ile $18,5^{\circ} \mathrm{C}$ arasında değiştiği ve bu sıcaklık değerlerinin Türkiye' de ekonomik anlamda zeytin üretiminin yapılabileceği alt ve üst sınır değerleri olduğu ve yıllık ortalama sıcaklığın $16.7^{\circ} \mathrm{C}$ olarak belirtmişlerdir. Bölgesel olarak yıllık ortalama sıcaklığın Güney Marmara ve Karadeniz kıyı kesiminde $15^{\circ} \mathrm{C}$ 'nin altında kalırken Akdeniz ve Güneydoğu Anadolu Bölgesi'nde $17^{\circ} \mathrm{C}$ 'nin üstüne çıkmaktadır. CBS teknikleri kullanılarak elde edilen analiz sonuçlarına göre ülkesel düzeyde zeytin üretiminin yapıldığı uygun alanlar için yıllık ortalama alt ve üst sıcaklık sınır değerlerinin $14,4^{\circ} \mathrm{C}$ ile $19.2^{\circ} \mathrm{C}$ arasında değiştiği ve yıllık ortalama sıcaklık değeri ise $16.8^{\circ} \mathrm{C}$ olarak belirlenmiştir. Zeytin üretiminin yoğun olarak yapıldığı bazı alanlarda ortalama sıcaklık değerleri; Silopi'de $19.0^{\circ} \mathrm{C}$, Bodrum'da $18.0^{\circ} \mathrm{C}$, Mut'ta $17.7^{\circ} \mathrm{C}$, Nizip'te $17.4^{\circ} \mathrm{C}$, Ayvalık'ta $16.2^{\circ} \mathrm{C}$, Akhisar'da $15.9^{\circ} \mathrm{C}$, Edremit'te $15.7^{\circ} \mathrm{C}$ ve Gemlik'te $14.8^{\circ} \mathrm{C}$ olarak belirlenmiştir.

Zeytin yetiştiriciliğini sınırlayan en önemli faktörlerden biri kış döneminde görülen düşük sıcaklıklardır. En soğuk ay olan Ocak, zeytin ağcının fizyolojik yaşamı bakımından dinlenme dönemidir. Zeytin bitkisi, günlük ortalama sıcaklığın $7.2^{\circ} \mathrm{C}$ ve altına düştüğü dönemlerde dinlenmeye çekilir. Zeytin üretiminin yoğun olarak yapıldığı bölgelerde, Ocak ayının ortalama değerleri $4,4^{\circ} \mathrm{C}$ ile $10^{\circ} \mathrm{C}$ 'ler arasında değişmektedir (Ayaz ve Varol, 2015). Zeytin ağacı biyolojik ve fizyolojik gelişiminde çiçek tomurcuğunun oluşabilmesi için belli bir soğuklama süresine intiyaç duymaktadır (Timuçin, 1993). Türkiye'de zeytin üretimine uygun alanlar içinde Ocak ayı ortalama sıcaklık değeri 4.9 ile $11.0^{\circ} \mathrm{C}$ arasında değişirken ortalama sıcaklık değeri $7.0^{\circ} \mathrm{C}$ 'dir. En yüksek Ocak ayı sıcaklık değerleri; Datça'da $11.0^{\circ} \mathrm{C}$, Bodrum'da $10.0^{\circ} \mathrm{C}$, Kaş'ta $9.7^{\circ} \mathrm{C}$ ve Milâs'ta $8.8^{\circ} \mathrm{C}$ gözlenmiştir. Diğer önemli zeytin üretim alanları incelendiğinde; Ayvalık'ta $7.4^{\circ} \mathrm{C}$, Mut'ta $7.4^{\circ} \mathrm{C}$, Edremit'te $6.7^{\circ} \mathrm{C}$, Gemlik'te $6.3^{\circ} \mathrm{C}$, Mudanya'da $5.9^{\circ} \mathrm{C}$ ve Nizip'te $5.6^{\circ} \mathrm{C}$ 'dir. Kış aylarında zeytinin soğuklama intiyacının karşılanmasında Akdeniz Bölgesi'nde sıcaklık şartları yer yer olumsuzluklar göstermektedir. Benzer ekolojik bölgelerde özellikle soğuklama intiyacının fazla olmasına bağlı olarak sürecin uzaması sebebiyle çeşit tercihlerinde dikkatli olunmalıdır.

Zeytin ağacının gelişiminde minimum sıcaklık dereceleri risk taşımaktadır. Zeytin dinlenme döneminde $0^{\circ} \mathrm{C}$ 'de dirençlidir. Sıcaklığın $-7^{\circ} \mathrm{C}$ 'den aşağı düşmesiyle ciddi zararlar oluşabilir. Zeytin üretiminin uygun olduğu alanların geneli dikkate alındığında mutlak minimum sıcaklık değerinin -5.5 ile $2.4^{\circ} \mathrm{C}$ arasında değiştiği ve ortalama sıcaklık derecesinin $-2.8^{\circ} \mathrm{C}$ olduğu belirlenmiştir. Mutlak minimum sıcaklığın en yüksek olduğu Ege Bölgesi'nin güneyinde; Datça'da $2.4^{\circ} \mathrm{C}$ ve Bodrum'da $0.9^{\circ} \mathrm{C}$ 'dir. Bu alanlarda, özellikle arızalı topoğrafik yapı öne çıkmaktadır. Bu değer diğer alanlar için Milas'ta $-0.9^{\circ} \mathrm{C}$, Söke'de $-1.0^{\circ} \mathrm{C}$, Ayvalık'ta $-2.1^{\circ} \mathrm{C}$, Mut'ta $-2.2^{\circ} \mathrm{C}$, Edremit'te $-2.9^{\circ} \mathrm{C}$, Gemlik'te $-3.5^{\circ} \mathrm{C}$, Mudanya'da $-3.8^{\circ} \mathrm{C}$ ve Nizip $-4.5^{\circ} \mathrm{C}$ 'dir.

Zeytin alanlarında çok yüksek nemin olması, sıcak etkisinin azalması ve bazı hastalıkların oluşmasına sebep olabilmektedir. Nem oranının \% 80'ni aştığı alanlarda zeytin ağacının hastalıklara yakalanma riski artmakta ve yağ kalitesinde olumsuz değişiklikler meydana gelmektedir (Gümüşçay ve Topuz, 2006). Zeytin yetiştirmeye uygun alanlarda nem oranları \% 51.3 ile \% 75 arasında değişirken, ortalama nem oranı \% 63.5 düzeyindedir. Bölgesel bazda ise nem oranı Marmara'nın kuzeyinden başlayarak Karadeniz boyunca \% 70'in üzerindedir.

Çiçeklenme, zeytin gelişimi için kritik bir aşamadır. Sıcaklık faktörü çiçeklenmeye yol açan süreçleri etkileyen en önemli faktörlerden biridir (Va'zquez et al., 2003; Orlandi et al., 2005). Mayıs ayı genellikle çiçeklenme dönemi olmakla beraber çeşitlerin soğuklanma intiyaçları ve ekolojik faktörlere göre Mayıs'ın ilk haftasından başlayıp son haftasına kadar devam etmektedir. Çiçeklenme döneminde sıcaklığın $30^{\circ} \mathrm{C}$ üzerine çıkması tozlanma ve döllenme için risk oluşturmaktadır (Bonofiglio, 2008). İlçe bazında yapılan CBS analizlerine göre Mayıs ayı sıcaklık değeri 16.5 ile 22.7 arasında değişirken, ortalama sıcaklık değerinin $19.6^{\circ} \mathrm{C}$ olduğu belirlenmiştir. Mayıs ayı sıcaklık değerinin ülkenin güney kesiminde $20.0^{\circ} \mathrm{C}$ ve üstüne çıkarken Marmara'nın güney kesiminde ise $17.5^{\circ} \mathrm{C}$ ve Karadeniz Bölgesinde ise $16.5^{\circ} \mathrm{C}$ civarlarına düşmektedir. İlçelere göre bu değerler; Nizip'te $21.1^{\circ} \mathrm{C}$, Bodrum'da $20.2^{\circ} \mathrm{C}$, Akhisar'da $19.5^{\circ} \mathrm{C}$, Edremit'te $18.9^{\circ} \mathrm{C}$, Gemlik'te $17.5^{\circ} \mathrm{C}$ ve Mudanya'da $17.4^{\circ} \mathrm{C}$ olarak belirlenmiştir.

Zeytin ağaçlarında kuraklık stresi meyve tutumunu, meyve boyutlarının küçülmesini, meyve olgunlaşmasını ve meyve yağ birikimini olumsuz etkilemektedir. Zeytin yetiştirilen alanlarda yıllık toplam yağışın $400 \mathrm{~mm}$ ve üzeri olması gerekir (Brito et al., 2019). Zeytin üretiminin yaygın olarak yapıldığı 
alanlarda yağış miktarları 305 ile 1060 mm arasında değişmektedir. Bu alanların geneli dikkate alındığında yağış ortalaması 668 mm'dir. Zeytin yetiştiriciliğine uygun alanlar da yağış miktarları; Marmaris'te 1043 mm, Altınözü'nde 890.6 mm, Gemlik'te 694 mm, Ayvalık'ta 623.9 mm, Akhisar'da $575.1 \mathrm{~mm}$, Mut'ta 424.3 $\mathrm{mm}$ ve Nizip'te 394.4 mm'dir.

Yüksek sıcaklıklara bağıı olarak zeytin ağaçlarında fizyolojik problemler görülebilir. Zeytin ağaçları $40^{\circ} \mathrm{C}$ 'e kadar yüksek sıcaklık derecelerine dayanabilmektedir (Temuçin, 1993). Yaz aylarında, Marmara Bölgesi'nde fizyolojik açıdan daha uygun koşullar oluşurken, Akdeniz ve Güneydoğu Anadolu Bölgesi'nde yüksek sıcaklıklar nedeniyle meyve gelişimi yavaşlamaktadır. Zeytin üretim alanlarında, Temmuz ve Ağustos ayları dikkate alındığında ortalama sıcaklık $23.8^{\circ} \mathrm{C}$ ile $33.5^{\circ} \mathrm{C}$ arasında değişmiştir. Yaz dönemi ortalama maksimum sıcaklık değeri $27.5^{\circ} \mathrm{C}$ 'dir. Güneydoğu Anadolu Bölgesi en yüksek sıcaklık değerlerinin görüldüğü bölgedir. Bu bölgede; Silopi'de $33.5^{\circ} \mathrm{C}$, Nizip'te $30.4^{\circ} \mathrm{C}$ ve Mut'ta $28.9^{\circ} \mathrm{C}$ 'dir. Diğer taraftan, Marmara Bölgesi'nin güney kesimi $24^{\circ} \mathrm{C}$ civarı sıcaklık dereceleriyle diğer bölgelere göre düşük sıcaklık değerlerine sahiptir.

Yükselti faktörü sıcaklık ve yağış üzerindeki etkisinden dolayı zeytinin yetişme alanları üzerinde sınırlayıcı bir rol oynamaktadır. Zeytin üretimi yapılan bölgeler de genel bir yaklaşım olarak yükselti arttıkça verimde azalma görülmektedir (Tunalıoğlu ve Gökçe, 2002). Zeytin yetiştiriciliğinde $600 \mathrm{~m}$ yükseltiye kadar optimum üretim yapılabilmektedir (Ayaz ve Varol, 2015). Üretim bölgeleri genelinde ortalama yükselti değeri $236 \mathrm{~m}$ olarak bulunmuştur. Zeytin üretim alanları içinde yer alan Güneydoğu Anadolu Bölgesi'nde Kilis'in 562 m, Nizip'in 481 m ve Akdeniz Bölgesi'nde Mut'un 290 m yükselti değerleri ile öne çıktığı görülmüştür.

Zeytin üretiminin, eğimi derecesi yüksek alanlarda yapılması ağaç başına verimi azalmaktadır. Düz arazilerde verim $20-24 \mathrm{~kg}$ arasında iken eğimin \% 20 olduğu yerlerde $11.7 \mathrm{~kg}$ ve $\% 40$ olduğu kesimlerde ise 5 kg'ın altına düşmektedir (Tunalıoğlu ve Gökçe, 2002). Türkiye'deki zeytinliklerin \% 75'i eğimli arazilerde bulunmaktadır (Efe ve ark., 2013). Uygunluk haritasında çok uygun alanların, Ege (\% 10.3) ve Akdeniz (\% 8.9) Bölgelerin de daha eğimli alanları içerdiği buna karşın, Marmara Bölgesinin güneyi (\% 5.5) ve Güneydoğu Anadolu Bölgesi (\% 2.3) sınır hattı boyunca daha düşük eğimli alanlarda yayılım göstermektedir (Çizelge 7).

Çizelge 7. Zeytin yetiştiriciliği için uygunluk sınıflarının alansal ve oransal dağılımı

Table 7. Area and proportional distribution of suitability classes for olive cultivation

\begin{tabular}{lcc}
\hline Uygunluk Sınıfları & Alan (ha) & Oran (\%) \\
\hline Çok uygun & 5254937 & 6.7 \\
Orta uygun & 4940932 & 6.3 \\
Az uygun & 3799108 & 4.9 \\
Uygun değil & 63985976 & 82.1 \\
\hline
\end{tabular}

Zeytin, toprak isteği bakımından birçok bitkiye göre daha toleranslıdır. Bununla birlikte, iyi toprak koşullarına sahip alanlar meyve kalitesi ve verim artışına önemli katkı sağlamaktadır. Zeytin ağacı, killi ve çok ağır toprak yapısına sahip olmayan tınlı, kumlu tınlı topraklarda çok iyi bir şekilde gelişir. Zeytin, taban suyu yüksek ve kötü drenajı olan araziler ile bitki gelişimini sınırlayıcı tuzluluk, asit ve alkalilik düzeyi yüksek olan topraklarda iyi bir gelişim gösteremez. Zeytin üretiminin yoğun olarak yapıldığı Ege ve Akdeniz Bölgesi tipik Akdeniz ekolojisini taşıyan eğimli ve tepelik alanları barındıran bir topoğrafik yapıya sahiptir. Bu alanların büyük bir kısmı sığ ve çok sığ toprak derinliğine sahiptir. AKK sınıfları açısından değerlendirildiğinde VI ve VII sınıf araziler oldukça yaygın olduğu görülmektedir. Bu alanların büyük bir kısmı şiddetli ve çok şiddetli erozyon riski taşımaktadır. Ova ve eğimi düşük alanlarda drenaj açısından sorunlar mevcuttur. Toprak bünyesinde suyun uzun süre kalması bitki kök gelişimi açısından problemler oluşturabilmektedir. Bu kapsamda, tarımsal araziler içinde yeteri derecede drene edilemeyen ve yeraltı suyu seviyesinin yüksek olduğu ve denize yakın bazı lokal alanlarda kötü drenaja sahip tuzlu ve alkali alanlar bulunmaktadır. Güneydoğu Anadolu Bölgesi ise özellikle sınır hattı boyunca Kilis'ten başlayarak Şırnak iline kadar tarım toprakları açısından oldukça elverişlidir. Bu alanlar, düz ve düze yakın eğimli ve toprak derinliği fazla olan I. sınıf arazileri içermektedir. 
Zeytin yetiştirilen tarım topraklarının sınıflandırılmasında; AKK, derinlik, KTO ve erozyon parametreleri değerlendirilmiştir. Zeytin yetiştiriciliğine çok uygun olan tarım topraklarını sınırlayıcı fiziksel bir özelliği bulunmayan veya hafif derecede sınırlılı̆a sahip alanları içermektedir. Orta derecede uygun topraklar, orta derecede erozyon ve toprak derinliği olan, yetersiz drenaj problemleri olan alanlardır. Az uygun alanlar; yüksek eğim derecesi ve şiddetli erozyona sahip, taşı, tuzlu veya alkali sınıfında bulunan toprak derinliği sığ olan alanlardır. Uygun olmayan alanlar ise çoğunlukla VIII sınıf arazilerin yer aldığı çok şiddetli erozyon riski taşıyan çıplak ve kayalık alanlar, toprak derinliği çok sığ alanlar ile tuzlu ve alkali çok kötü drenajlı alanları oluşturmaktadır. KTO kapsamında, Büyük Toprak Grupları içerisinde yer alan Hidromorfik topraklar, Alüvyal Sahil toprakları, Organik topraklar ve Yüksek Dağ Çayır toprakları tarım dışı alanlar içerisinde değerlendirilmiştir.

Zeytin yetiştiriciliğinde uygun alanların oluşturulmasında, CBS'de her kriter için elde edilen uygunluk haritaları doğrusal kombinasyon metoduna göre birleştirilerek potansiyel uygunluk haritası oluşturulmuştur (Şekil 5). Uygunluk sınıfları, uygunluk indis değerlerinin sınıflandırılması ile elde edilmiştir. Bu kapsamda; çok uygun (1-0.85), orta uygun (0.85-0.6), az uygun (0.6-0.4) ve uygun değil (0.4-0) sınıfları oluşturulmuştur (FAO, 1985). Zeytin yetiştiriciliği için oluşturulan uygunluk sınıflarının, \% 6.7'si (5 254937 ha) çok uygun ve \% 6.3'ü (4 940932 ha) orta uygun sınıfta yer alırken, \% 4.9'u (3 799108 ha) az uygun ve \% 82.1'i (63985976 ha) ise uygun olmayan sınıf içerisinde yer almıştır (Çizelge 7).

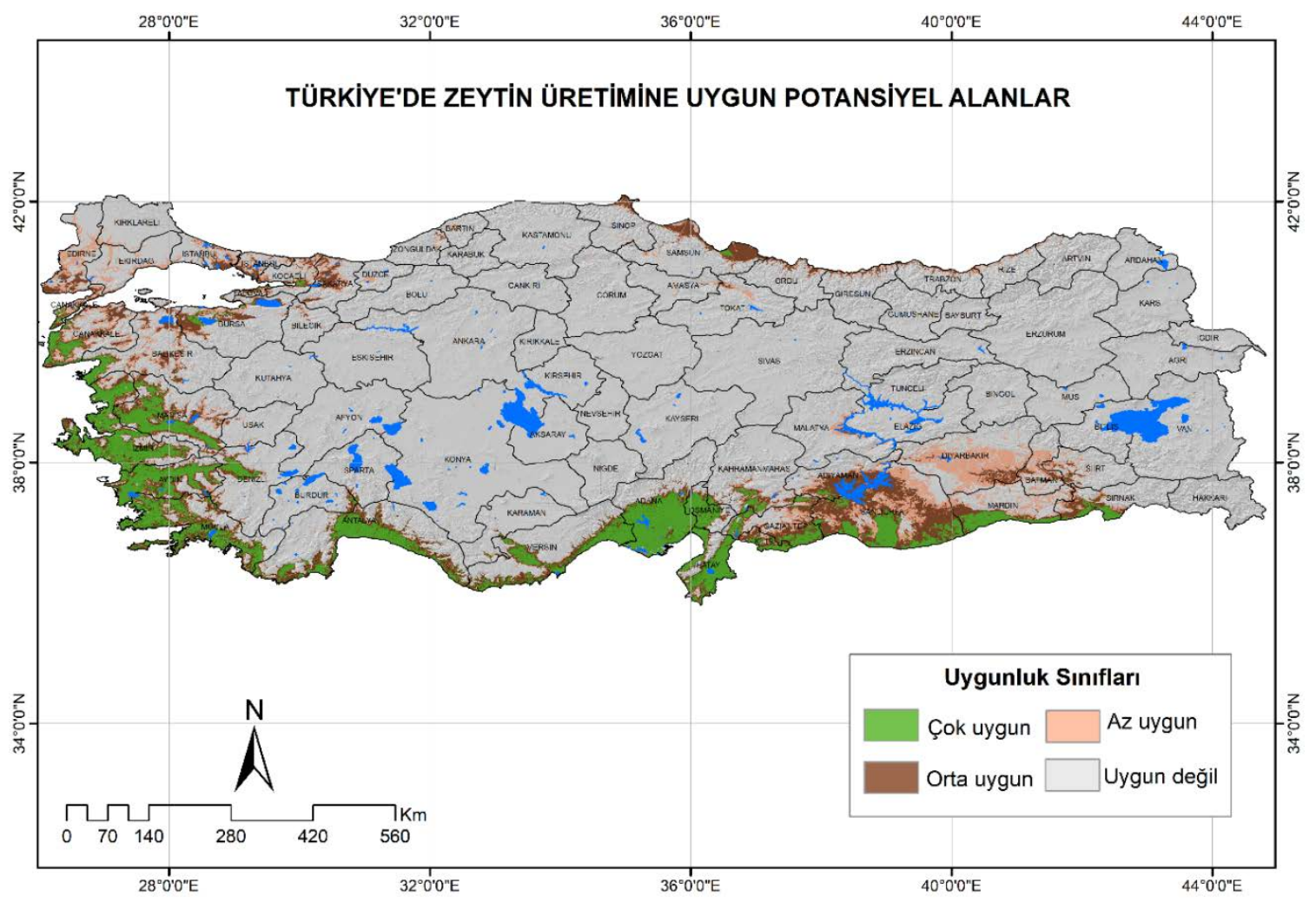

Şekil 5. Zeytin yetiştirmeye uygun potansiyel alanlar haritası.

Figure 5. Map of potential areas suitable for olive growing.

Zeytin üretiminde, Ege Bölgesi en uygun koşullara sahip bölgedir. Bölgede dağların kıyı şeridine dik olarak uzanması sebebiyle Akdeniz ikliminin etkisi özellikle; Büyük ve Küçük Menderes ve Gediz gibi nehir vadileri boyunca iç kesimlere nüfuz edebilmektedir. Bu topoğrafik yapı kıyıdan 200 km iç bölgelere kadar zeytin yetiştiriciliğine uygun şartlar oluşturmaktadır. Ege bölgesinde, uygunluk analizinden elde edilen alansal ortalama değerlere göre yıllık ortalama sıcaklık $16.8^{\circ} \mathrm{C}$, yıllık yağış miktarı $671.0 \mathrm{~mm}$ ve yükselti $176.5 \mathrm{~m}$ olarak belirlenmiştir (Çizelge 8). 
Zeytin yetiştiriciliği için uygun iklim şartlara sahip diğer bir bölgemiz olan Akdeniz Bölgesinde, Ege Bölgesinin aksine dağların kıyıya paralel uzanması nedeniyle zeytin yetiştiriciliğine uygun alanlar tipik Akdeniz ikliminin etkisi altındaki kıyı şeridinde yapılmaktadır. Toros dağlarının kuzeye bakan iç kesimlerinde karasal iklim hakim olduğundan zeytin yetiştiriciliği mikro klima oluşturan, Mut (Mersin), Sütçüler (Isparta) ve Bucak (Burdur) gibi ilçelerin sınırlı alanlarında yapılabilmektedir. Akdeniz Bölgesi, yıllık ortalama sıcaklık $18.1^{\circ} \mathrm{C}$, Ocak ayı mutlak minimum sıcaklık $-1.0^{\circ} \mathrm{C}$ ve Ocak ayı ortalama sıcaklık $8.8^{\circ} \mathrm{C}$ değerleri ile en sıcak bölgedir (Çizelge 8).

Karasal ikliminin genellikle hakim olduğu Güneydoğu Anadolu Bölgesi'nde zeytincilik ancak Akdeniz ikliminin kısmen etkilediği alanlarda yapılmaktadır. Son yıllarda, GAP projesinin devreye girmesiyle iklim şartlarında oluşan olumlu şartlar yetiştiriciliğin sınırını Fırat nehrinin doğusundan daha iç kesimlere taşınmıştır. Güney Doğu Anadolu Bölgesi zeytin yetiştiriciliği yapılan bölgeler arasında ortalama yükseltisi en yüksek $(475 \mathrm{~m}$ ) bölgedir. Bölgede gelişim dönemi boyunca yüksek sıcaklık ve buharlaşma kısıtlayıcı bir faktör oluşturmaktadır. Güneydoğu Anadolu Bölgesi zeytin yetiştiriciliği yapılan alanlar içerisinde yıllık ortalama sıcaklığı $17.8^{\circ} \mathrm{C}$ ile ortalama değerin üstünde olmasına karşın Ocak ayı sıcaklıkları yönünden mutlak minimum sıcaklık $-4.7^{\circ} \mathrm{C}$ ve Ocak ayı ortalama sıcaklık $5.5^{\circ} \mathrm{C}$ değerleri ile en soğuk bölge konumundadır (Çizelge 8). Bununla beraber üretimin yapıldığı uygun alanlarda yıllık yağış toplamının $435 \mathrm{~mm}$ civarında olması nedeniyle sulama imkanı koşulları ilave tedbir olarak düşünülmelidir. Bu bölgemizde, Kilis ve Gaziantep illeri öne çıkarken sınır boyunca Şırnak iline kadar uzanan alanda potansiyel üretim alanları içinde yer almaktadır.

Çizelge 8. Zeytin üretimi yapılan uygun alanların bölgesel bazda ekolojik parametre değerleri

Table 8. Ecological parameter values of regional olive production areas

\begin{tabular}{lccccccccc}
\hline Bölgeler & $\begin{array}{c}\text { Yıllık ort. Sıc. } \\
\left({ }^{\circ} \mathrm{C}\right)\end{array}$ & $\begin{array}{c}\text { Mutlak min. } \\
\text { Sıc. }\left({ }^{\circ} \mathrm{C}\right)\end{array}$ & $\begin{array}{c}\text { Ocak ort. } \\
\text { Sıc. }\left({ }^{\circ} \mathrm{C}\right)\end{array}$ & $\begin{array}{c}\text { Mayıs ort. } \\
\text { Sıc. }\left({ }^{\circ} \mathrm{C}\right)\end{array}$ & $\begin{array}{c}\text { Yağış } \\
(\mathrm{mm})\end{array}$ & $\begin{array}{c}\text { Temmuz } \\
\text { Ort. Sıc. }\left({ }^{\circ} \mathrm{C}\right)\end{array}$ & $\begin{array}{c}\text { Nem } \\
(\%)\end{array}$ & $\begin{array}{c}\text { Yükselti } \\
(\mathrm{m})\end{array}$ & $\begin{array}{c}\text { Eğim } \\
(\%)\end{array}$ \\
\hline Marmara & 15.2 & -3.2 & 6.3 & 18.0 & 638.0 & 25.2 & 69.9 & 71.2 & 5.5 \\
Ege & 16.8 & -2.3 & 7.7 & 19.8 & 671.0 & 27.3 & 62.7 & 176.5 & 10.3 \\
Akdeniz & 18.1 & -1.0 & 8.8 & 20.7 & 801.5 & 27.7 & 64.4 & 174.8 & 8.9 \\
Güneydoğu & 17.8 & -4.7 & 5.5 & 21.7 & 436.7 & 31.3 & 55.2 & 474.6 & 2.3 \\
Karadeniz & 14.4 & -2.5 & 6.9 & 15.8 & 837.4 & 23.4 & 72.9 & 34.4 & 2.9 \\
\hline
\end{tabular}

Marmara Bölgesi; Akdeniz, Karadeniz ve karasal iklim gibi farklı iklim şartlarının görüldüğü ve gerçek anlamda değerlendirildiğinde zeytin yetiştiriciliği açısından ekstrem özelliklere sahiptir. Bölgenin büyük kısmı soğuk kuzey rüzgarlarının etkisi altında olup zeytincilik ancak kuzeye kısmen kapalı alanlarda ve sahil bölümlerinin güneye bakan kesimlerinde yapılabilmektedir. Ancak bu alanlarda bile yetiştiricilik açısından büyük riskler söz konusudur. Marmara Bölgesi zeytin yetiştiriciliği yapılan alanlar dikkate alındığında $15.2^{\circ} \mathrm{C}$ ile yıllık ortalama sıcaklık değerinin $1.6^{\circ} \mathrm{C}$ altında yer almıştır. Zeytincilik yetiştiriciliği açısından en önemli iller; Bursa, Çanakkale ve Balıkesir'dir. Kocaeli, Sakarya, Tekirdağ ve İstanbul gibi illerde lokal alanlar da uygunluk söz konusu olup küçük çaplı yetiştiricilik yapılabilmektedir.

Zeytin yetiştiriciliği için Karadeniz Bölgesi ekstrem bir bölge konumundadır. Bölgenin batı kısmı kuzey rüzgarlarına karşı açık olup kış döneminde soğukların etkisi altında kaldığından genellikle zeytincilik için uygun şartlara sahip değildir ve zeytin yetiştiriciliği açısından riskli bir bölgedir. Doğu Karadeniz kesiminde ise Kafkas dağlarının koruyucu etkisi sebebiyle kışlar daha ılık geçmektedir. Dolayısıyla, zeytin yetiştiriciliği kuzey rüzgarlarından korunmuş Artvin'den Sinop'a kadar uzanan kıyı kesiminde ve ırmak vadilerinde (Çoruh Vadisinin Artvin-İspir arası, Harşit Çayı Vadisi, Tortum Vadisi, Durağan Çukuru, Boyabat Oluğu, Kelkit Oluğu vb.) daha çok öz tüketim amacıyla sofralık zeytincilik yapılmaktadır (Usta ve ark., 2014). Karadeniz Bölgesi'nde zeytin yetiştiriciliğine uygun alanlar, yıllık ortalama sıcaklığı $14.4^{\circ} \mathrm{C}$ ile alt sınırdadır. Uygunluk haritasında bölgenin büyük bölümü orta uygun sınıfta yer almıştır. 


\section{SONUÇ}

Zeytin, hem ekolojik hem de ekonomik açıdan çok değerli ve önemli bir üründür. Ürünün yetişme koşullarına ve verime etki eden unsurlar arasında kültürel ve ıslah yöntemleri ile genetik özelliklerinin yanı sıra fiziksel faktörlerin etkisinin de önemi büyüktür. Ürüne ait ekolojik veri tabanlarının oluşturularak potansiyel yetişme alanlarının belirlenmesi tarımsal planlama için öncelikli bir konudur. Ayrıca, zeytin yetiştiriciliği yapılan alanlardaki ekolojik farklılıkların ürünün verim ve kalitesine olan etkilerinin belirlenmesi önem taşımaktadır.

Doğru arazi kullanım kararları ile arazinin optimum kullanımı, çevrenin korunması ve sürdürülebilirliğine olumlu katkı sağlamaktadır. Düşük arazi uygunluğu nedeniyle tarımsal amaçlar için uygun olmayan marjinal araziler fiziksel yetersizlik veya erozyon gibi çevresel riskleri içerebilir ve kaynakların sürdürülebilir kullanımını engelleyebilir. Zeytin yetiştiriciliği yapılan alanlar ekolojik dengenin korunması açısından da önem taşımaktadır. Marjinal alanlarda yer alan yabani zeytinliklerin; biyoçeşitlilik, yangın kontrol bölgeleri, erozyon kontrolü vb. çevre yönetiminde kullanımları da söz konusudur.

Bu çalışmada, zeytin için belirlenen iklim, toprak ve topoğrafik faktörlere göre ekolojik veri tabanı oluşturulmuş ve dört sınıfı potansiyel uygunluk haritası üretilmiştir. Elde edilen harita, ülkesel bazda yapılacak planlamalarda ve ürün desteklemelerinde kullanılabilecektir. Ayrıca; yapılması düşünülen lokal, bölgesel ve çeşit bazındaki çalışmalar için altık oluşturacaktır.

Zeytin üretiminde bölgesel bazda farklılıklar sebebiyle yetiştiricilik açısından özellikle çeşit seçimi önem taşımaktadır. Zeytin, normal çiçeklenme için belirli bir süre düşük sıcaklık (soğuklama) gereksinimi duymaktadır. Bu nedenle daha sıcak ekolojiler de zeytinin çiçeklenme süresi uzayabilir hatta bazı çeşitler için normal çiçeklenme gösteremeyebilir. Dolayısıyla, ekonomik değeri yüksek ve yaygın üretim alanı bulunan çeşitler için ekolojik istekleri ve çevresel faktörler modellenerek bölgesel bazda ürünün adaptasyon haritalarının oluşturulması doğru ürün planlaması için önem taşımaktadır.

Ülkemizde, Marmara Bölgesi'nin güneyinden başlayarak Ege ve Akdeniz ve Güneydoğu Anadolu Bölgesinde Kilis ve Gaziantep (Nizip) ile devam eden ve sınır hattı boyunca Silopi'ye kadar uzanan bölge zeytin yetiştiriciliği için uygun alanları içermektedir. Ülke genelinde, zeytin üretimine çok uygun yetişme alanlarına ait iklim özellikleri; yıllık ortalama sıcaklığın $16.8^{\circ} \mathrm{C}$, mutlak minimum sıcaklık $-2.8^{\circ} \mathrm{C}$, Ocak ayı ortalama sıcaklık $7.0^{\circ} \mathrm{C}$, Mayıs ayı ortalama sıcaklık $19.6^{\circ} \mathrm{C}$ ve yıllık toplam yağış $668 \mathrm{~mm}$ olarak belirlenmiştir.

Zeytin yetiştiriciliğinde, Ege ve Akdeniz bölgeleri en uygun sıcaklık ve yağış koşullarını taşımaktadır. Marmara bölgesi ortalama sıcaklık değerleri; Ege, Akdeniz ve Güneydoğu Anadolu Bölgesinde sınır boyunu içine alan bölgeye göre 1.5 ile $2.5^{\circ} \mathrm{C}$ daha düşük sıcaklık değerlerine sahiptir. Karadeniz bölgesinde zeytin üretimi sınırlı bir alanda yapılmaktadır. Bu alanlarda ortalama sıcaklık değeri yetiştiricilik yapmaya uygun koşul değerlerinin alt sınırı seviyesinde yer almıştır. Buna karşın Güney Doğu Anadolu Bölgesinde özellikle sınır hattı boyunca zeytin yetiştiriciliği için uygun alanları içermektedir. Zeytin kuraklığa karşı töleranslı bir ürün olmasına karşın yüksek sıcaklıklar ve yıllık yağış miktarındaki düşüklükler verim ve kaliteyi olumsuz etkilemektedir. Bu bölge de sulama yapılan alanlarda üretimi olumlu etkileyen koşullar söz konusudur.

Zeytin yetiştiriciliğine orta derecede uygun alanlar da yetersiz drenaj, taşlılık, erozyon, hafif tuzluluk ve alkalilik gibi kısıtlayıcı toprak özelliklerinin olduğu ama ekonomik açıdan ürünün verim potansiyeli olduğu için tarımsal planlama açısından değerlendirilmelidir. Az uygun sınıfta yer alan zeytinlikler, $600 \mathrm{~m}$ yükseltinin üzerinde ve eğim değerinin \% 20'nin üstüne çıktığı şiddetli ve çok şiddetli erozyona maruz kalan alanlarda yer almaktadır. Ayrıca, bu alanlar, kötü drenaj, tuzluluk, alkalilik sorunu olan alanları da içermektedir. Bu alanların ciddi fiziksel kısıtlardan dolayı ekonomik açıdan yeterli miktarda ürün alınması zordur. Diğer taraftan, bu alanlar arazi bozunumu, erozyon kontrolü ve biyoçeşitlilik açısından önem taşımakta ve çevre yönetimi yönünden değerlendirilmesi daha uygundur.

Zeytin üretimi yapılan alanlar iklim, toprak ve topoğrafik faktörlerin sınırlayıcı etkisi altındadır. Bu ana faktörlere bağlı birçok alt faktörün olması Çok Kriterli Değerlendirme (ÇKD) yönteminin öne çıkmasını sağlamıştır. Ayrıca, faktörlerin birbirlerine göre önem derecelerinin belirlenmesinde Analitik Hiyerarşi Süreci (AHS) yaklaşımı ile ağırık oranları hesaplanmıştır. ÇKD yöntemi ile CBS teknikleri bir arada uygulanarak çok fazla faktörün içinde olduğu karmaşık yapıların modellenmesinde etkin olarak kullanılmıştır. 


\section{KAYNAKLAR}

Aguilera, F., Ruiz-Valenzuela, L., 2009. Study of the floral phenology of Olea europaea L. in Jaen province (SE Spain) and its relation with pollen emission. Aerobiologia 25, 217-225.

Anonim, 2006. Zeytin Yetiştiriciliği Kitabı TAGEM Yayın No: 61 Izmir.

Ayaz, M. ve Varol, N. 2015. İklim Parametrelerindeki Değişimlerin (Sıcaklık, Yağış, Kar, Nispi Nem, Sis, Dolu ve Rüzgar) Zeytin Yetiştiriciliği Üzerine Etkileri. Zeytin Bilimi 5 (1), 33-40.

Ayehu, G. T. and Besufekad, S. A. 2015. Land Suitability Analysis for Rice Production: A GIS Based Multi-Criteria Decision Approach. American Journal of Geographic Information System 2015, 4(3): 95-104 DOI: 10.5923/j.ajgis.20150403.02

Beaufoy, G. 1998. "The reform of the CAP olive-oil regime: What are the implications for environment?" Hampshire:European Forum on Nature Conservation and Pastoralisme. Occasional publication No 14.

Bonofiglio, T., Orlandi, F., Sgromo, C., Romano, M. 2008. Influence of temperature and rainfall on timing of olive (Olea europaea) flowering in sothern Italy. New Zealand Journal of Crop and Horticultural Science, 2008, Vol. 36: $59-69$.

Brito, C., Dinis, L-T., Moutinho-Pereira, J., M. Correia, C. 2019. Drought Stress Effects and Olive Tree Acclimation under a Changing Climate. Plants, 8, 232.

Brunelli, M. 2014. Introduction to the analytic hierarchy process. pp. 82, New York, NY: USA, Springer Briefs in Operations Research.

Ceballos-silva, A. and Lopez-Blanco, J. 2003. Delineation of Suitable Areas for Crops Using a Multi-Criteria Evaluation Approach and Land Use/Cover Mapping: A Case Study in Central Mexico, Agricultural Systems. 77, 117-136.

Drobne, S. and Lisec, A. 2009. Multi-attribute decision analysis in GIS: weighted linear combination and ordered weighted averaging. Informatica: An International Journal of Computing and Informatics, 33(4), 459-474.

Eastman, J. R., Jin, W., Kyem, P. A. K., Toledano, J. 1995. Raster procedures for multicriteria/multiobjective decisions. Photogrammetry and Remote Sensing. 61(5); 539-547.

Efe, R., Soykan, A., Cürebal, İ., Sönmez, S. 2013. Dünyada, Türkiye'de, Edremit Körfezi Çevresinde Zeytin ve Zeytinyağı. Edremit Belediyesi Kültür yayınları No:7, ISBN: 978-605-62253-0-7.

Efe, R., Soykan, A., Sönmez, S., Cürebal, İ. 2009. Sıcaklık şartlarının Türkiye'de Zeytinin (Olea europaea L. subsp. europaea) Yetişmesine, Fenolojik ve Pomolojik Özelliklerine Etkisi. Ekoloji, 18, 70, 17-26.

ESRI, 2011. ArcGIS Desktop: Release 10. Redlands, California: Environmental Systems Research Institute.

FAO, 1976. A Framework for Land Evaluation. Soils Bulletin No. 32, Food and Agricultural Organization of the United Nations, Rome, Italy.

FAO, 1985. Guidelines: land evaluation for irrigated agriculture. FAO Soils Bulletin 55.

FAO, 2018. FAOSTAT, http://www.fao.org/faostat/en/\#data/QC

Galán, C., García Mozo, H., Vázquez, L., Ruíz-Valenzuela, L., Díaz de la Guardia, C.,Domínguez-Vilches, E., 2008. Modeling olive crop yield in Andalusia-Spain. Agronomy Journal 100 (1), 98-104.

Gucci, R. and Fereres, E. 2012. "Fruit trees and vines. Olive," in Crop Yield Response to Water. FAO Irrigation and drainage paper 66 (Rome: Food and Agriculture Organization of the United Nations), 300-313.

Guo, X., Yan, D., Fan, J., Zhu, W., Li, M. 2010. Using GIS and Fuzzy Sets to Evaluate the Olive Tree's Ecological Suitability in Sichuan Province. Computing in Science and Engineering. Volume: 12 , Issue: 1, 20-27, 10.1109/MCSE.2010.17, IEEE.

Guzman Alvarez, J. R. 1999. Olive cultivation and ecology: The situation in Spain. Olivae 78: 41-49.

Guzman Alvarez, J. R. and Navarro Cerrillo, R. M. 2008. Modelling potential abandonment and natural restoration of marginal olive groves in Andalusia (south of Spain). Journal of Land Use Science, Vol. 3, No. 2-3,113-129.

Gümüşay, B. ve Topuz, H. 2006. Zeytinde Zararlı Böcekler, T.C. Tarım ve Köyişleri Bakanlığı Tarımsal Araştırmalar Genel Müdürlüğü Zeytincilik Araştırma Enstitüsü Müdürlüğü. Emre Basımevi, İzmir.

Günden, C. ve Miran, B. 2008. Bulanık Analitik Hiyerarşi Süreci Kullanılarak Çiftçi Kararlarının Analizi. Ege Üniverstesi, Ziraat Fak. Dergisi, 2008, 45 (3): 195-204.

Hossain, M. S. and Das, N. G. 2010. GIS-based multi-criteria evaluation to land suitability modelling for giant prawn (Macrobrachium rosenbergii) farming in Companigonj Upazila of Noakhali,Bangladesh. Computers and Electronics in Agriculture 70, 172-186. 
Hutchinson, M.F. 1995. Interpolating Mean Rainfall Using Thin Plate Smoothing Splines. Int. J. Geogr. Info. Systems, 9, 385-403.

Hutchinson, M.F. 2000. ANUSPLIN Version 4.1. User Guide, Center for Resource and Environmental Studies, Australian National University, Canberra.

Jankowski, P. 1995. Integrating geographical information systems and multiple criteria decision-making methods. International Journal of Geographical Information Science 9: 251-273.

Kazemi, H. and Akinci, H. 2018. A land use suitability model for rainfed farming by Multi-criteria Decision making Analysis (MCDA) and Geographic Information System (GIS). Ecological Engineering 116, 1-6.

Koca, N. 2004. Çanakkale'de Zeytin Yetiştiriciliğinin Coğrafi Esasları. Marmara Coğrafya Dergisi Sayı:9, İstanbul.

Liu, F., Peng, Y., Zhang, W., Pedrycz, W. 2017. On consistency in AHP and Fuzzy AHP. Journal of Systems Science and Information, 5(2), 128-147.

Malczewski, J. 1999. GIS and Multicriteria Decision Analysis. New York: Wiley.

Malczewski, J. 2004. GIS-Based Land-Use Suitability Analysis: A Critical Overview, Prog. Plann, 62, 3-65 2004.

MGM, 2019. Internet sitesi, https://www.mgm.gov.tr/veridegerlendirme/il-ve-ilceleristatistik.aspx?k=parametrelerinTurkiyeAnalizi (Erişim tarihi: 04.01.2019)

Montazar A., Behbahani , S. M. 2007. Development of an optimized irrigation system selection model using analytical hierarchy process. Biosystems Eng 98:155-165.

Nzeyimana, I., Hartemink, A. E., Geissen, V. 2014. GIS-Based Multi-Criteria Analysis for Arabica Coffee Expansion in Rwanda. PLOS ONE, 9(10), pp 1-9.

Orlandi, F., Sgromo, C., Bonofiglio, T., Ruga, L., Romano, B., Fornaciari, M. 2010. Yield modelling in a Mediterranean species utilizing cause-effect relationships between temperature forcing and biological processes. Scientia Horticulturae123, 412-417.

Orlandi, F., Vazquez M. N., Ruga, L., Bonofiglio, T., Fornaciari, M., Garcia-Mozo, H., Dominguez, E., Romano, B., Carmen, G. 2005. Bioclimatic Requirements for Olive Flowering In Two Mediterranean Regions Located at The Same Latitude (Andalucia, Spain And Sicily, İtaly). Ann Agric Environ med, 12, 47-52.

Oteros, J., García-Mozo, H., Hervás-Martínez, C., Galán, C. 2013. Year clustering analysis for modelling olive flowering phenology. International Journal of Biometeorology 57 (4), 545-555.

Pertziger, F. and De Pauw. E. 2002. CLIMAP, An Excel-Based Software for Climate Surface Mapping. ICARDA, Aleppo, Syria.

Rossiter, D.G. 1996. A theoratical framework for land evaluation. Geoderma, 72:165-202.

Saaty, T. L. 1980. The Analytical Hierarchy Process, McGraw Hill, New York.

Saaty, T.L. and Vargas, L.G. 2001. Models, Methods, Concepts \& Applications of Analytical Hierarchy Process, International Series in Operations Research and Management Sciences, New York.

Shalaby, A., Ouma, Y. O., Tateishi, R. 2006. Land suitability assessment for perennial crops using remote sensing and Geographic Information Systems: A case study in northwestern Egypt. Archives of Agronomy and Soil Science 52 (3), 243-261.

Sofo, A., Manfreda, S., Fiorentino, M., Dichio, B., Xiloyannis, C. 2008. The olive tree: a paradigm for drought tolerance in Mediterranean climates. Hydrology and Earth System Sciences.12:293-01.

SYS, C., Van Ranst, E., Debaveye, J., Beernaert, F. 1993. Crop Requirements, Part III. Agricultural publications No:7, General Administration for development Cooperation, Brussels, pp: 247.

Temuçin, E. 1993. Türkiye'de Zeytin Yetişen Alanların Sıcaklık değişkenine Göre İncelenmesi, Ege Coğrafya Dergisi 7, 117-131, İzmir-Türkiye.

Therios, I. 2009. Olives: Crop Production Science in Horticulture 18. CABI Publishing; Wallingford, UK.

TUIK, 2016. İnternet sitesi, https://biruni.tuik.gov.tr/medas/?kn=92\&locale=tr. (Erişim tarihi: 01.09.2019)

Tunalıoğlu, R. ve Gökçe, O. 2002. Ege Bölgesi'nde Optimal Zeytin Yayılış Alanlarının Tespitine Yönelik Bir Araştırma. Tarım ve Köylşleri Bakanlığı, Tarımsal Ekonomi Araştırma Enstitüsü Yayınları. Ankara

Usta, A. Aybar, M. Bayram, S. Akçay, S. 2014. Akdeniz Bölgesinin Bir Maki Elemanı olan Zeytinin Trabzonda'ki Yerel Yayılımının Ekolojik Açıdan İncelenmesi. II Ulusal Akdeniz Orman ve Çevre Sempozyumu.

Va'zquez, L. M., Gala'n, C., Domı'nguez-Vilches, E. 2003. Influence of meteorological parameters on olea pollen concentrations in Co'rdoba (South-western Spain). International Journal Biometeorology, 48, 83-90. 